\title{
From Systemic Inflammation to Neuroinflammation: The Case of Neurolupus
}

\author{
Mykolas Bendorius ${ }^{1}$, Chrystelle Po ${ }^{2}$, Sylviane Muller ${ }^{1,3}$ [D and Hélène Jeltsch-David 1,*(i) \\ 1 UMR 7242 Biotechnologie et Signalisation Cellulaire, École Supérieure de Biotechnologie de \\ Strasbourg (ESBS), Laboratoire d'Excellence Médalis, Université de Strasbourg/CNRS, 67412 Illkirch, \\ France; mbendorius@unistra.fr (M.B.); sylviane.muller@unistra.fr (S.M.) \\ 2 ICube UMR 7357, Université de Strasbourg/CNRS, Fédération de Médecine Translationnelle de Strasbourg, \\ 67000 Strasbourg, France; chrystelle.po@unistra.fr \\ 3 University of Strasbourg Institute for Advanced Study (USIAS), 67000 Strasbourg, France \\ * Correspondence: hdavid@unistra.fr; Tel.: +33-368-855-103
}

Received: 12 October 2018; Accepted: 9 November 2018; Published: 13 November 2018

check for updates

\begin{abstract}
It took decades to arrive at the general consensus dismissing the notion that the immune system is independent of the central nervous system. In the case of uncontrolled systemic inflammation, the relationship between the two systems is thrown off balance and results in cognitive and emotional impairment. It is specifically true for autoimmune pathologies where the central nervous system is affected as a result of systemic inflammation. Along with boosting circulating cytokine levels, systemic inflammation can lead to aberrant brain-resident immune cell activation, leakage of the blood-brain barrier, and the production of circulating antibodies that cross-react with brain antigens. One of the most disabling autoimmune pathologies known to have an effect on the central nervous system secondary to the systemic disease is systemic lupus erythematosus. Its neuropsychiatric expression has been extensively studied in lupus-like disease murine models that develop an autoimmunity-associated behavioral syndrome. These models are very useful for studying how the peripheral immune system and systemic inflammation can influence brain functions. In this review, we summarize the experimental data reported on murine models developing autoimmune diseases and systemic inflammation, and we explore the underlying mechanisms explaining how systemic inflammation can result in behavioral deficits, with a special focus on in vivo neuroimaging techniques.
\end{abstract}

Keywords: autoimmunity; systemic lupus erythematosus (SLE); neuropsychiatric lupus (NPSLE); murine model; magnetic resonance imaging (MRI); blood-brain barrier; behavior

\section{Introduction}

The effects of systemic inflammation on the central nervous system (CNS) are quite well illustrated in neuropsychiatric systemic lupus erythematosus (NPSLE), a poorly understood, severe form of systemic lupus erythematosus (SLE) disease that can affect up to 75\% of SLE patients. This dramatic form of lupus disease covers a wide range of manifestations that are divided into focal and diffuse ones. Focal symptoms (e.g., seizures, cerebrovascular disease, aseptic meningitis) usually result from a stroke occurring in a specific structure and can be readily detected by magnetic resonance imaging (MRI), while diffuse symptoms (e.g., depression, cognitive dysfunction, mood and anxiety disorders, acute confusional state, psychosis), however, are much harder to identify accurately by MRI and can have debilitating consequences for patients as well. It is thought that diffuse symptoms proceed due to neuroinflammatory processes both in the periphery and the CNS, which we seek to explore in this review. After summarizing the main features of the pathology and the mouse models that recapitulate 
the human disease in terms of peripheral inflammation and behavioral deficiencies, we inquire into how advanced MRI techniques can be used non-invasively in mice to identify NPSLE symptoms and how this might translate to the human disease. At last, the way in which neuroinflammation may cause central nervous symptoms in these murine lupus-prone models is explored.

\section{Systemic and NP Aspects of Lupus Disease}

\subsection{General Presentation of SLE}

SLE is a chronic relapsing-remitting autoimmune disease characterized by a rupture of self-tolerance and systemic inflammation mainly resulting from the hyperactivation of peripheral $\mathrm{B}$ and $T$ cells [1], resulting in high levels of pathogenic autoantibodies (autoAbs), tissue deposition of immune complexes, and, ultimately, multiple and various organ injuries (e.g., skin, kidneys, heart, lungs, brain) [2-4]. The disease primarily affects females of childbearing age (90\% of patients) [5], and its etiology, which appears multigenic, is not fully understood due to it being also influenced by hormonal and environmental factors (e.g., UV radiation, diet, smoke, infections, pollutants, stress) [6-8].

\subsection{CNS Involvement in Human SLE: The Neuropsychiatric Lupus Disease (NPSLE)}

Depending on the study, a varying number of SLE sufferers (from 15\% to $75 \%$ ) present with neuropsychiatric (NP) symptoms that cover the whole spectrum of psychiatric dysfunction $[9,10]$. These NP manifestations are associated with a reduced quality of life [11-13] and, when severe, they substantially contribute to the morbidity and mortality rates of SLE patients [14]. Nowadays, the etiology of NPSLE remains poorly understood, as is also the case for SLE and most autoimmune diseases.

In 1999, the American College of Rheumatology (ACR) recognized 19 wide-ranging NP manifestations related to SLE [15]: some affect the CNS, in which case they can be focal or diffuse [16], and the others affect the peripheral nervous system (Table 1). This widely adopted classification was meaningful from a clinical point of view but presents some limitations with respect to the variety of symptoms and their specific attribution to SLE [11]. In 2001, Ainiala et al. revised this original categorization and discarded certain minor NP symptoms, such as headaches and anxiety disorders $[17,18]$. When compiling recently published data, it clearly appears that this novel classification has affected the NPSLE prevalence values, pointing to the lack of consensus on straightforward and uncontroversial NPSLE diagnosis (e.g., definition of impairment, selection of patients and of cognitive tests used). Since then, various NPSLE diagnostic criteria have been proposed but none of them have achieved both high sensitivity and specificity [19]. In fine, there is currently no consensus about inclusion or exclusion criteria for NPSLE, resulting commonly in an overdiagnosis of NPSLE and the administration of unnecessary immunosuppressive treatments.

Table 1. ACR case classification of the NP manifestations described in SLE [15].

\begin{tabular}{|c|c|c|}
\hline Central Nervous System & & Peripheral Nervous System \\
\hline Cerebrovascular disease & Depression & Cranial neuropathy \\
\hline Aseptic meningitis & Mood and anxiety disorders 1 & Mononeuropathy (single/multiplex) \\
\hline Movement disorder & Psychosis & Polyneuropathy \\
\hline Myelopathy & Acute confusional state & Plexopathy \\
\hline \multirow[t]{2}{*}{ Demyelinating syndrome } & Headaches $^{1}$ & Myasthenia gravis \\
\hline & & $\begin{array}{l}\text { Acute inflammatory demyelinating } \\
\text { polyradiculoneuropathy } \\
\text { (Guillain-Barré syndrome) }\end{array}$ \\
\hline
\end{tabular}

${ }^{1}$ Anxiety disorders and headaches have been removed in the revised classification suggested by Ainiala et al. (2001) [18]. According to Hanly et al. (2018) [11], posterior reversible encephalopathy syndrome, neuromyelitis optica spectrum disorder, and small fiber neuropathy should be included in a future revision of the ACR classification. Abbreviations: ACR, American College of Rheumatology; NP, neuropsychiatric; SLE, systemic lupus erythematosus. Adapted from Jeltsch-David and Muller (2014) [10]. 
One critical problem with the diagnosis of NPSLE remains the lack of objective and specific biomarkers. Therefore, this aspect remains eminently challenging. Today, NPSLE is essentially clinically defined by physical examination, serological measures, psychological and neurological evaluations, and brain imaging. Hopefully, rapidly advancing progress in live imaging technology will help and allow the establishment of reliable and specific diagnostic criteria for NPSLE.

Twenty autoAbs (11 brain-specific and 9 systemic) [20] and several cytokines found in the serum, but more specifically in the cerebrospinal fluid (CSF) of patients, have been linked to NPSLE [10]. Focal manifestations can be detected by MRI techniques and reflect, usually, cerebral vasculopathy, thrombosis, and complement activation $[10,11,16]$. The presence of antiphospholipid (aPL) autoAbs in the CSF correlates with some of these events [16]. Diffuse symptoms are harder to identify [21] and seem related, instead, to inflammation elicited by several mediators (e.g., interferon (IFN) $\alpha$, anti-N-methyl-D-aspartate receptor (NMDAR and anti-ribosomal $\mathrm{P}$ autoAbs), which induce not only leakage of the blood-brain barrier (BBB) but also other barriers, as briefly addressed below [22-27].

The brain is protected from the periphery by three distinct structural and functional interfaces with systemic circulation: the BBB, the blood-CSF barrier (BCSFB), and the meningeal barrier [28]. These entities comprise endothelial cells (ECs) connected by tight junctions that prevent free passage of soluble macromolecules and cells, control the influx of nutrients and efflux of toxic molecules, and maintain a regulated microenvironment optimal for neuronal signaling $[29,30]$. The BBB has been proposed to be leaky both in SLE patients and lupus-prone mice [31], resulting in the deleterious diffusion of proinflammatory factors. In humans, this alteration has been evidenced mainly by the presence of serum albumin and immunoglobulins $\mathrm{G}$ (IgGs) in the CSF $[26,32,33]$ and through the use of MRI [34]. Previously, it was claimed that BBB disruption was directly responsible for the passage of peripheral molecules to the brain, initiating NPSLE disease. However, recent data obtained from experiments with mice argue that the peripheral molecules reach the brain through the BCSFB rather than via the BBB [22], providing interesting hypotheses in favor of BCSFB leakage in human patients as well [35], and refining the BBB leakage dogma.

\subsection{Modelization of the Disease in Mice}

There are obvious limits to the search for mechanisms of CNS disease in human patients. Thus, murine models offer several advantages for elucidating the early mechanisms of NP manifestations of SLE and help to distinguish between CNS-specific and -nonspecific mechanisms [36]. Neuroinflammatory mechanisms of NPSLE are quite well recapitulated in lupus-prone murine models that develop a lupus-like disease [37], including NP events, manifesting through the production of autoAbs in the serum [38] and CSF [39,40]. Some animal models are spontaneous, as the BXSB mice, the Murphy Roths Large (MRL) mice, and the F1 hybrid of the New Zealand Black (NZB) and New Zealand White $(\mathrm{NZW})$ mouse strain (called $(\mathrm{NZB} \times \mathrm{NZW}) \mathrm{F} 1)$ [41]. Others are genetically engineered, such as the 564Igi mouse [42,43]. All these murine models help to provide valuable insights into how the CNS can be affected by systemic inflammation. Nevertheless, after the identification of autoAbs targeting the brain, NPLSE-like inducible NPSLE models have also been developed. In these induced models, human autoAbs are passively injected or, alternatively, mice are immunized against these specific brain self-antigens, leading to the development of NPLSE-like disease without the severe peripheral autoimmune damage [44-47]. Even if none of these animal models reflect the human disease perfectly, they all provide some key elements involved in the disease's pathogenesis, leading to the development of safer and more efficient treatments, as was very well depicted in a recent review [48].

The MRL/lpr strain is one of the best-established spontaneous models of SLE and is the most commonly investigated in lupus-related NP studies. This strain displays an autoimmune phenotype, and its composite genome is derived from LG/J (75\%), AKR/J (12.6\%), C3H/HeDi (12.1\%), and C57BL/6J (0.3\%) mice [49]. MRL/lpr mice spontaneously develop an autosomal recessive lymphoproliferation (lpr) mutation affecting the Fas gene [50]. Identified as an intron deletion in the Fas gene, this mutation leads to aberrant Fas mRNA splicing [50] and the loss of protein expression [51]. 
Interestingly, this mutation does not necessarily increase the proliferative capacity of lymphocytes but rather allows them to escape the negative and positive selection processes [50,51]. The parental strain of MRL/lpr mice, the MRL/MpJ mouse (also named $\mathrm{MRL}^{+/+}$later in the text), does not carry the lpr mutation and develops the autoimmune syndrome, albeit weaker and delayed in life, thus representing a natural and adequate control [52]. Over the past decade, the MRL/lpr exhibited a "fortuitous attenuation" of symptoms of still unknown origin, and the MRL/lpr original stock was re-established in 2008 (http://jaxmice.jax.org/strain/006825.html) [36,41].

The disease developed by MRL/lpr mice mimics human SLE. In particular, in both settings, a leaky BBB and the presence of circulating autoAbs directed against dsDNA and Smith (Sm) antigen are observed, the only serological biomarkers of SLE in humans. As in human SLE, where a strong gender preference is usually described (9:1 female to male ratio), female MRL/lpr mice develop a more severe disease [41]. Finally, comparable to some NP symptoms evidenced in SLE patients, autoimmune MRL/lpr mice spontaneously develop pathological changes in the brain and an autoimmunity-associated behavioral syndrome (e.g., depression, emotional and cognitive dysfunction) that can be characterized with a battery of behavioral tests, summarized below (Figure 1). However, it is important to emphasize that, in this murine model, the disease-associated brain atrophy remains poorly understood.

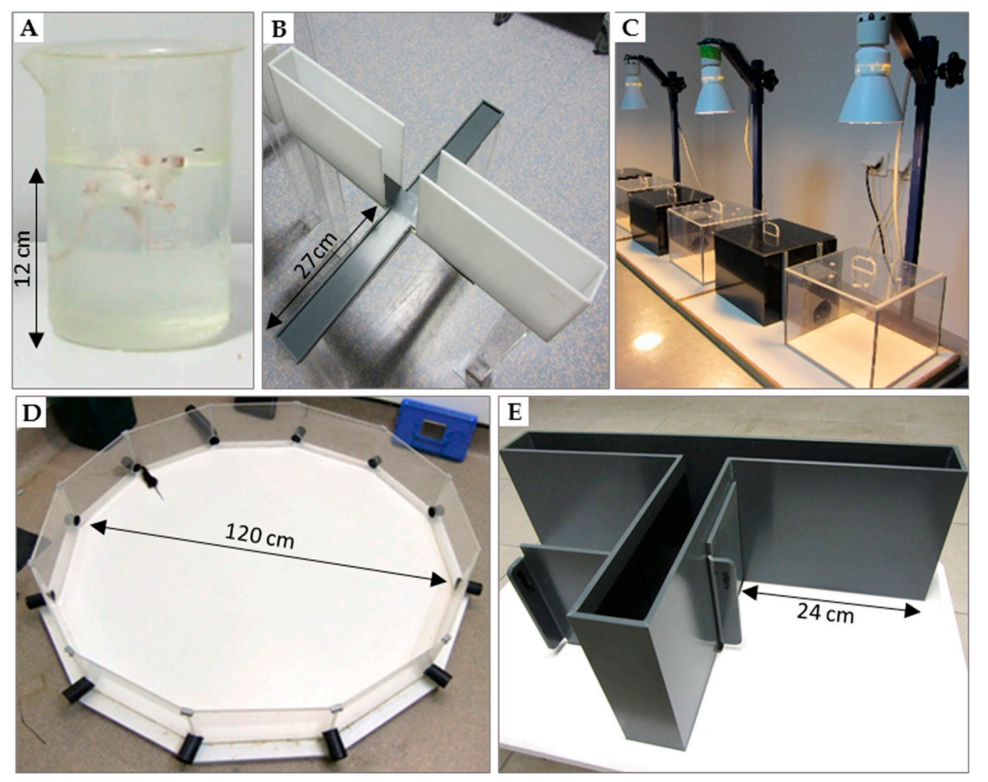

Figure 1. Tests used for behavioral evaluation of mice. (A) Forced-swim test (or Porsolt test) used to assess depressive-like behavior; (B) elevated plus-maze and (C) dark/light preference test to measure anxiety-like behavior; (D) Morris water maze (or paddling test) [53]; (E) T-maze that is considered very sensitive to alteration in hippocampal pathways.

\subsubsection{Tests of Depression}

- Forced-swim test (Porsolt test; Figure 1A)

In this experimental procedure, a mouse is forced to swim in a small container without the possibility to escape. Quickly, after a time of struggling and swimming, the animal stops any attempt of escape and becomes almost motionless (e.g., floating on the water surface and moving its limbs only to rebalance itself). Periods of activity alternate with periods of immobility, and the duration of the latter increases with time. Within this framework, immobility objectivizes behavioral helplessness and is interpreted as behavioral "distress" that ensues when the animal realizes that it cannot escape [54]. This model of behavioral despair is repeatedly validated by the pharmacological plan to detect the efficacy of antidepressants. The quicker the animal becomes immobile and stops trying to escape, i.e., the longer it stays immobile, the greater extent to which it is thought to display depressive 
symptoms. As compared to their parental $\mathrm{MRL}^{+/+}$littermates used as controls, MRL/lpr mice exhibit defects [55-57] implying an autoimmunity-associated syndrome.

- Sucrose preference test

This test evaluates deficiencies in motivated and goal-directed behavior and anhedonia, i.e., a reduced sensitivity to positive stimuli. Here, MRL/lpr mice manifest a reduced preference for palatable drinking solutions with sucrose compared to control $\mathrm{MRL}^{+/+}$mice. This observation is well established and can be detected both early in life and later during disease progression [57-61].

- Open-field locomotor activity test

Depressive-like manifestations also include apathy and fatigue, which are reflected as a decrease in spontaneous exploration of a novel environment, like an open field. Generally, as compared to control mice, MRL/lpr mice show such a decrease in spontaneous locomotion $[55,56,62]$.

\subsubsection{Anxiety Tests}

- Elevated plus-maze and dark/light preference tests (Figure 1B,C)

The elevated plus-maze and the dark/light preference tests are usually implemented in pharmacology for the screening of anxiolytic molecules [63-65]. The plus-maze test consists of a cross structure with two arms with walls (closed arms) and two wall-free arms (open arms). The dark/light preference test consists of two boxes, one is dark and the other is well lit, and an opaque tunnel that connects the dark box with the lit one. Both tests create an approach-avoidance conflict between the natural tendency of mice to explore and their aversion to open or brightly lit spaces. Generally, the more anxious the animal is, the less it will venture and stay in the open or lit compartments. Some debatable results have been reported in MRL/lpr mice with the elevated plus-maze test. Sakić and colleagues observed anxiety in MRL/lpr mice, i.e., diminution of the time spent in the open arms [55], while other groups noted the opposite result, with MRL/lpr mice being significantly less anxious than their $\mathrm{MRL}^{+/+}$littermates $[57,66,67]$. An important experimental difference between these two sets of studies is that some experiments were conducted with males [55] and others with females $[57,66,67]$.

- Open-field test

The open-field test is sometimes used to measure anxiety-related behavior, as quantified by the duration for which the mouse avoids the central part of a novel enclosed arena and remains in close proximity of the walls (thigmotaxis) $[68,69]$. In this test, as compared to control $\mathrm{MRL}^{+/+}$mice, MRL/lpr mice disclose anxiety-like behavior, as evidenced by increased thigmotaxis and impaired exploration of space $[55,57]$.

Controversial results have been reported for open-field and elevated plus-maze tests that might be explained by the use of different strains and sex of mice [70,71]. To discuss the absence of consensus in detail is beyond the scope of this essay but, as well depicted in an exhaustive review, it is worth mentioning that independent of the strain, male and female mice display inherently different anxiety-coping mechanisms [72]. Potential processes underlying sex differences in anxiety states include emerging evidence supporting the existence of two anatomically and functionally distinct serotonergic circuits that modulate conflict anxiety and panic-like anxiety, respectively. Regarding the MRL/lpr strain, female MRL/lpr mice seem to display, as in human SLE, a strong bias in severity (e.g., higher levels of IgG in the CSF) [40] and rate of progression of the autoimmune disease (e.g., earlier apparition of serum autoAbs) [57], which manifest in stronger cerebral pathology [56,66,73]. Therefore, sex differences in the expression of anxiety behavior are not surprising or unexpected in MRL/lpr mice.

\subsubsection{Cognitive Tests}

The detection of cognitive deficits in animals seems to be task-dependent. This finding is hardly surprising with regard to the fact that there are multiple "types" of memory, which are differently 
sensitive to brain damages [74]. Even if the three tests listed below are classified as "cognitive" tasks, they do not measure the same "cognitive processes" (working (or short-term) visual memory in the novel object recognition test [75], spatial working and reference (or long-term) memory in the Morris water maze, spatial working memory in the T-maze that is also sensitive to nonspatial learning aspects (e.g., temporal discriminations) [76]). Furthermore, these tests differ in terms of perceptual stimuli cueing choice behavior, and their accomplishments rely on different mechanisms, some being noncognitive (e.g., motivational factors), subserved by the activity of many brain regions.

- Novel object recognition test

This test is based on the tendency of rodents to preferentially explore novel objects. First, a mouse is placed into an arena and allowed to explore two identical novel objects. After a fixed period of exploration (defined as rearing on the object, whisking, sniffing, touching with nose and/or forepaws), the mouse is removed. Next, one of the objects is changed to a novel object and the mouse is reintroduced into the arena. Mice naturally tend to explore novel objects, so the duration of exploring the novel object is taken as the measure of visual working memory. In this paradigm of testing, MRL/lpr mice perform as well as $\mathrm{MRL}^{+/+}$controls [66] or even outperform them [57].

- Morris water maze (Figure 1D)

The Morris water maze test evaluates spatial memory in rodents [77]. The animal is placed into a tank filled with opaque water in which a platform is hidden beneath the surface. In this aversive situation, mice must learn using spatial cues placed in the testing room to navigate and find the platform. Longer latencies to find the platform reflect poorer performances. In this test, MRL/lpr mice show pronounced thigmotaxic swimming but no clear-cut impairment in learning/memory abilities compared to $\mathrm{MRL}^{+/+}$littermates $[56,78,79]$.

- The T-maze alternation test (Figure 1E)

This test, shaped like the letter $\mathrm{T}$, is based on the willingness of rodents to explore a new environment, i.e., they prefer to visit a new arm of the maze rather than the familiar one. The solving of this task consists of two turns, i.e., right and left. Mice are first placed in the start arm of the T-maze. Upon leaving the start arm, they choose between entering either the left or the right goal arm. With repeated trials, the animals show less tendency to enter a previously visited arm. The percentage of alternation (number of turns in each goal arm) is recorded. This test is currently used to evaluate cognitive deficits in mice and test novel chemical entities for their effects on cognition. The T-maze test is well known as particularly sensitive for detecting hippocampal dysfunction [80-83]. In MRL/lpr mice, alternation impairments have been evidenced as compared to the $\mathrm{MRL}^{+/+}$counterparts $[84,85]$, strongly supporting cognitive and, more specifically, hippocampal dysfunction in these mice.

\subsubsection{Locomotor function}

\section{- Beam-walking test}

The beam-walking test assesses the capacity of mice to coordinate movement on a narrow beam [67]. Mice are placed on the beam and the latency to cross and the number of paw slips are recorded. Interestingly, female MRL/lpr mice do not display locomotor deficits compared to their control $\mathrm{MRL}^{+/+}$ littermates [49,50]. However, males perform significantly worse [50]. The precise mechanisms of this sex difference remain unclear but might be due to different hormonal backgrounds [86].

Other tests assessing locomotor functions have been described, such as the pole test and string agility test, for example $[68,69]$. These tests, which require a good driving agility, give an idea of the integrity of proprioceptive and vestibular pathways. Generally, they are used in order to quantify the effects of either alterations in the CNS (motor cortex), those of various neuromuscular pathologies, or those of fatigue on the fine motricity and proprioceptive functions. These tests also allow checking for the presence of possible sensory-motor biases, which could affect observations obtained in other tests. 
The characterization of specific inflammatory factors giving rise to an autoimmunity-associated behavioral syndrome has contributed to the development of NPSLE inducible murine models. For example, some NP features have been observed in $\mathrm{C} 3 \mathrm{H} / \mathrm{HeJ}$ mice after ribonucleoprotein $\mathrm{P}$ human autoAb intracerebroventricular injection [87]. Anti-NMDAR Abs effects have been studied following injection of human anti-dsDNA Abs into the hippocampi of C57BL/ 6 mice [46] or immunization of BALB/c mice with the DWEYS peptide $[44,45,88,89]$. To date, only a few inducible models have been yet developed, but it is anticipated that a growing number of relatively specific models of NPSLE will be generated in the nearest future. Taken together, we can conclude that spontaneous and inducible NPSLE models fairly well recapitulate the human disease and provide important insights into how systemic inflammation can induce CNS damage. This central aspect is discussed below.

\section{Neuroimaging in NPSLE}

\subsection{Magnetic Resonance Imaging Modalities}

As already mentioned, two distinct, but potentially complementary, pathogenic mechanisms are distinguished in NPSLE: (i) vascular/thrombotic injury, likely implicating aPL Abs; and (ii) inflammation-mediated injury, implicating other pathogenic autoAbs, proinflammatory cytokines (e.g., interleukin (IL)-6, IFN $\alpha$ ), and disruption of the BBB, the latter being favored, among other factors, by the activation of the complement system and binding of immune complexes to ECs $[90,91]$. Nowadays, implementation of noninvasive anatomical and functional neuroimaging modalities is highly recommended for the identification of outcomes of pathogenic mechanisms that impact the structure, metabolism, and functionality of the brain.

MRI detects signals thanks to the properties of hydrogen nuclei in water and fat molecules, which are found in biological tissues, including the brain. It is the most relevant neuroimaging technique for the detection of structural alterations in the CNS (e.g., cortical atrophy, focal periventricular and subcortical white matter lesions, diffuse gray matter changes, reduced volume of the corpus callosum or the hippocampus) [92]. It is thus particularly sensitive to detecting acute focal NP manifestations [93-101]. Unfortunately, its diagnostic value remains limited since, in the case of diffuse manifestations, MRI usually gives unremarkable results or shows nonspecific abnormalities. To make matters worse, cerebral MRI abnormalities can be observed in SLE patients without NP symptoms and are even sometimes detected in healthy individuals [102-104].

Today, several advanced imaging modalities exist. These include diffusion-weighted imaging (DWI) [105], magnetic transfer imaging (MTI) [106], magnetic resonance angiography (MRA) [107], magnetic resonance spectroscopy (MRS) [108], diffusion tensor imaging (DTI) [109], and blood oxygen level-dependent functional MRI (BOLD-fMRI) [93], and they ideally could be implemented for identifying functional hallmarks of NPSLE and allow its diagnosis [11,110]. These methods are not detailed here, as this review rather focuses on data obtained in preclinical research performed on murine NPSLE models.

\subsection{Brain Imaging and MRL/lpr Mice}

In NPSLE preclinical research, MRI remains, unfortunately, rarely used, largely due to the high cost necessary for its implementation. However, some data in relation with anatomical findings have been generated and are summarized below.

- MRI

Atrophied cerebral structures in MRL/lpr mice were identified several years ago using paraformaldehyde (PFA)-fixed MRL/lpr brain [111]. Atrophy was noticeable in the superior colliculus, periaqueductal gray matter, pons, and midbrain. However, as PFA fixation could affect both brain morphology and MRI data [112], the conclusions raised from these studies remain to be confirmed.

We recently compared the brain morphology of 16-week-old female $\mathrm{MRL}^{+/+}(\mathrm{n}=10)$ and MRL/lpr $(\mathrm{n}=9)$ mice based on transverse relaxation time (T2)-weighted imaging (T2WI) MRI. MRI was 
performed using a 7/30 Biospec system (Bruker Biospin, Ettlingen, Germany) with ParaVision 6.0.1 software. Transmission was achieved with a quadrature volume resonator (inner diameter of $86 \mathrm{~mm}$ ), and a standard mouse brain quadrature surface coil $\left(\sim 19 \times 19 \mathrm{~mm}^{2}\right)$ was used for signal reception (Bruker BioSpin, Ettlingen, Germany). A T2WI axial anatomical dataset was acquired using the RARE sequence $(256 \times 256$ acquisition matrix, 23 slices, $0.5 \mathrm{~mm}$ slice thickness, in-plane resolution of $78 \times 78 \mu^{2}$, repetition time (TR) of $3 \mathrm{~s}$, echo time (TE) of $30.6 \mathrm{~ms}$, RARE-Factor of 8). Animals were anesthetized with $2 \%$ isoflurane, the respiration was noninvasively monitored using a magnetic resonance-compatible system, and the body temperature was maintained constant at $37-38^{\circ} \mathrm{C}$. In this study, an asymmetrical enlargement was noticeable in MRL/lpr brains (Figure 2A,B) with significantly increased ventricular volume on the left side, as demonstrated by the increased left/right ratio for ventricular volume $(p=0.035$; Figure 2C). Interestingly, a significant loss of brain weight was noted in diseased MRL/lpr mice ( $p=0.022$; Figure 2D), but no difference concerning the CSF volume could be noted between $\mathrm{MRL}^{+/+}$and MRL/lpr mice ( $p=0.842$; Figure 2E). Ventricular dilation and cerebral atrophy have also been previously reported in human NPLSE patients [94]. The meaningful enlargement of the left ventricle in MRL/lpr mice remains largely unstudied but might reveal lateralized brain damage [113] that, for example, has already been observed in neurodegenerative diseases [114]. Such asymmetry might be viewed as a major feature of the disease, which also raises questions on the nature of this lateralization.

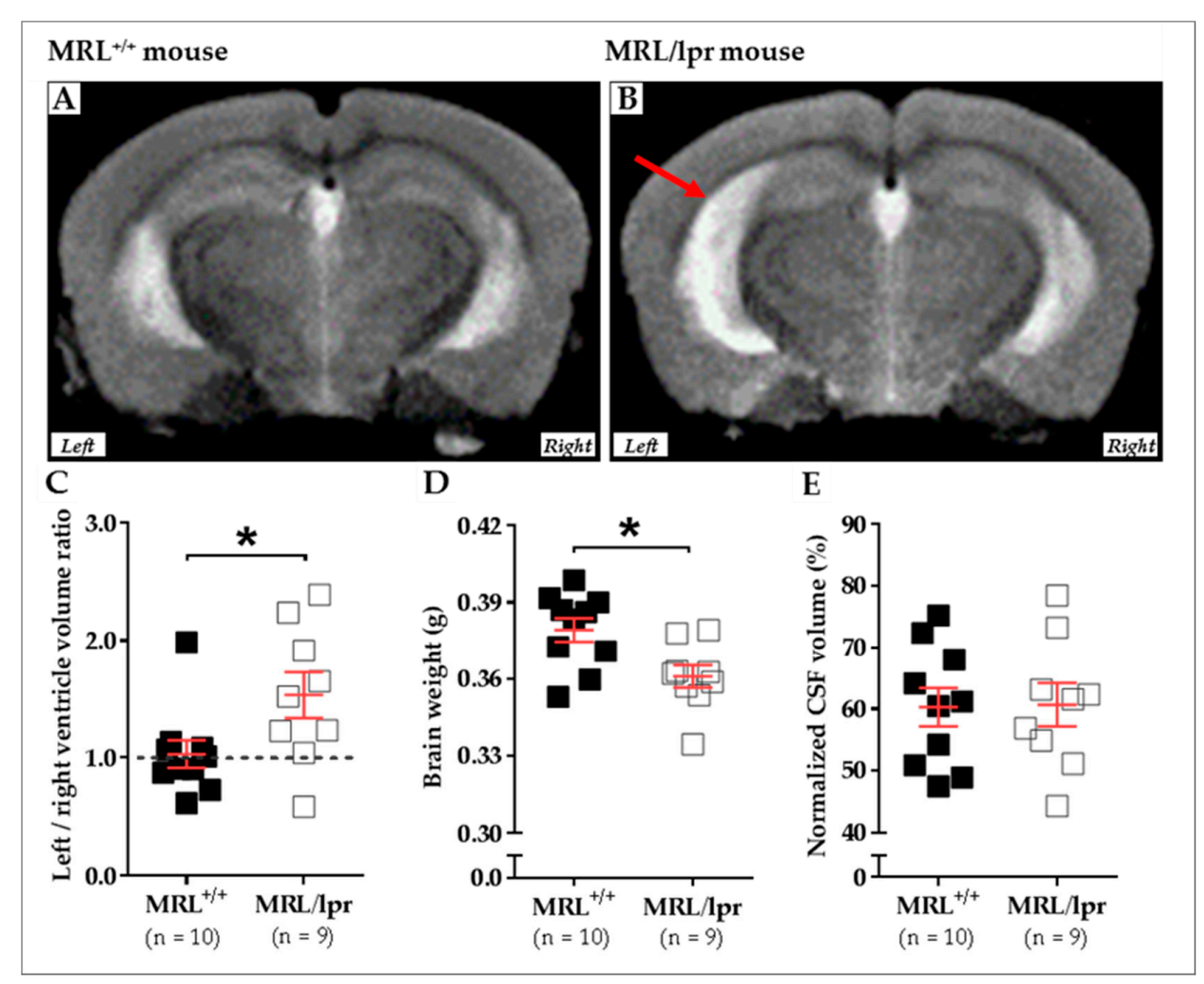

Figure 2. Cerebral abnormalities measured in $\mathrm{MRL}^{+/+}$and MRL/lpr mice. Conventional mid-axial T2-weighted MRI revealed a dilation of ventricles (red arrow) in 16-week-old female MRL/lpr mice (B) as compared to the age-matched counterparts $\mathrm{MRL}^{+/+}$mice (A). In the MRL/lpr strain, this enlargement is more remarkable on the left side, as revealed by analysis of the right/left ventricle volume ratio (C). Furthermore, a significant loss of brain weight was detected in these mice (D), even if the normalized volume of CSF did not show significant difference between both strains (E). Statistics: All data were analyzed with unpaired $t$ test, and significance was defined as $p<0.05\left(^{*}\right)$ Errors bars are mean standard deviation. Sample size is indicated as n. Abbreviations: CSF, cerebrospinal fluid; lpr, lymphoproliferation; MRI, magnetic resonance imaging; MRL, Murphy Roths Large. 


\section{- MEMRI}

MEMRI is a relatively new imaging technique that is not dependent on blood flow. As a paramagnetic contrast agent, $\mathrm{Mn}^{2+}$ is of special interest in neuroimaging, as it enhances MRI contrast in vivo by shorting both $\mathrm{T} 1$ (longitudinal) and T2 (transverse) relaxation times. $\mathrm{Mn}^{2+}$ ions enter neurons and excitable cells during the excitation phase through voltage-gated calcium channels. As such, MEMRI has unique capabilities for defining cerebral architecture, mapping neuronal pathways, and studying connectivity in morphological and functional imaging studies [115].

This MRI modality was applied to explore the olfactory pathway in mice with experimental NPSLE induced after intracerebroventricular injection of anti-ribosomal-P Abs [116]. Passive transfer of anti-ribosomal-P Abs induced a depressive-like behavior with a significant deficit in olfactory function. MEMRI of these mice demonstrated significant reduction in normalized $\mathrm{Mn}^{2+}$ enhancement ratios of olfactory structures, as compared to control mice. Thus, an impaired olfactory neuronal function in mice with experimental depression, mediated by passive transfer of human-anti-ribosomal-P Abs, can be spotted by MEMRI.

- ${ }^{1} \mathrm{H}-\mathrm{MRS}$

MRS uses the principles of MRI and, as with nuclear magnetic resonance spectroscopy, allows identification of specific metabolites in vivo at concentrations ranging from 0.5 to $10 \mathrm{mM}$. ${ }^{1} \mathrm{H}-\mathrm{MRS}$ determines the ${ }^{1} \mathrm{H}$ spectra of molecules [117]. The molecules that can be studied include choline-containing compounds (markers of cellular membrane turnover), creatine (involved in energy metabolism), $\mathrm{N}$-acetylaspartate (NAA; marker of neuronal viability), and lactate (marker of anaerobic metabolism, necrosis, and/or infections). ${ }^{1} \mathrm{H}$-MRS is more sensitive than MRI, evidencing lesions in white and gray matter that appear normal in a conventional MRI of SLE patients.

${ }^{1} \mathrm{H}-\mathrm{MRS}$ studies have shown significant metabolic differences between $\mathrm{MRL}^{+/+}$and lupus-prone mice in the hippocampus and the cortex [66], structures that, as we already emphasize in this review, are involved in the regulation of cognition and memory. In MRL/lpr mice, these metabolic abnormalities were shown to reflect dysfunction of neuronal (and/or glial) activity, but they did not correlate to structural changes that were detectable by MRI [66]. Both methods are, therefore, necessary to generate a complete picture.

MRI data evidencing an altered cerebral metabolic state in MRL/lpr mice confirm insights on the neuroinflammatory mechanisms of NPSLE in these mice. One major advantage of MRI is its applicability in vivo, allowing the real-time study of the disease progression. At this stage, additional investigations have to be carried out to understand the reasons for the ventricular system asymmetry in MRL/lpr mice, a phenomenon never described until now.

\section{Neuroinflammation in Lupus-Prone Mice}

\subsection{Characteristic Elements Occurring in the Brain of Lupus-Prone Mice}

A summary of the different autoAbs and cytokines detected in MRL/lpr mice and suspected to play a role in NPSLE is shown in Table 2.

\subsubsection{Pathogenic AutoAbs}

Evidence supporting the role of autoAbs in the CNS pathology and subsequent negative behavioral outcomes includes the higher levels of autoAbs in the serum of diseased MRL/lpr mice that develops earlier in females $[57,66]$ (for extensive reviews, see [36,41]).

There is further demonstration that some of these serum autoAbs recognize brain antigens, such as a subtype of NMDAR glutamate $[118,119]$, an excitatory neurotransmitter. When injected directly into the brain of healthy mice, or when injected peripherally into animals with a breached BBB, these autoAbs are neurotoxic and induce deficits in cognition and emotional behavior $[46,120]$. We focus attention on this issue in greater detail in Section 4.3. 
Intrathecal administration of anti-ribosomal P Abs induces depression-like behavior in the forced swim test [87]. The relation between serum or CSF levels of autoAbs and NPSLE disease processes is complex, but it is likely that intrathecal CSF brain-reactive autoAbs titers [39] may be more critically related to NPSLE pathogenesis and symptoms than serum ones [121].

Table 2. Potential NPSLE biological hallmarks found in MRL/lpr mice.

\begin{tabular}{|c|c|c|c|}
\hline Hallmarks & Location & Levels/Expression & References \\
\hline \multicolumn{4}{|c|}{ AutoAbs } \\
\hline aPL (e.g., anticardiolipin) & Serum & Increased levels & [122] \\
\hline Anti-dsDNA & Serum & Increased levels & [123] \\
\hline Anti-nucleosome * & Serum & Increased levels & [124] \\
\hline Anti-ribosomal P protein & Serum & Increased levels & [125] \\
\hline Anti-Sm & Serum & Increased levels & [125] \\
\hline Anti-ribosomal S10 & Serum & Increased levels & [126] \\
\hline Anti-NMDAR & Serum & Increased levels & {$[57,66]$} \\
\hline \multicolumn{4}{|c|}{ Cytokines } \\
\hline IL-1 $\beta$ & $\begin{array}{l}\text { Serum } \\
\text { CNS }\end{array}$ & Increased levels & [127-130] \\
\hline$I L-2$ & T cells & Decreased expression & {$[131,132]$} \\
\hline IL-6 & $\begin{array}{l}\text { Serum } \\
\text { CSF }\end{array}$ & Increased levels & {$[127,133-135]$} \\
\hline$I L-9$ & Serum & Increased levels & {$[128,130,136]$} \\
\hline IL-10 & $\begin{array}{l}B \text { cells } \\
\text { CNS }\end{array}$ & Dysregulation & {$[128,130,137,138]$} \\
\hline IL-12 & Serum & Increased levels & [139] \\
\hline$I L-17$ & Serum & Increased levels & [140] \\
\hline$I L-18$ & Serum & Increased levels & {$[141,142]$} \\
\hline$I L-21$ & Serum & Dysregulation & [143] \\
\hline$I L-22$ & Serum & Increased levels & [144] \\
\hline M-CSF & Serum & Increased levels & [145] \\
\hline MIF & Serum & Increased levels & [146] \\
\hline$I F N \gamma$ & $\begin{array}{c}\text { Splenocytes } \\
\text { CNS }\end{array}$ & Dysregulation & {$[128,147,148]$} \\
\hline $\mathrm{TNF} \alpha$ & Serum & Increased levels & {$[127,129,149]$} \\
\hline TWEAK & CNS & Tendency to increase & [150] \\
\hline \multicolumn{4}{|c|}{ Receptors } \\
\hline$s I L-6 R$ & Serum & Increased levels & [133] \\
\hline Fn14 (TWEAK receptor) & CNS & Increased levels & [150] \\
\hline
\end{tabular}

${ }^{*}$ Molecules indicated in italics are those for which relevance in NP manifestations remains to be confirmed. Abbreviations: aPL, antiphospholipid; CSF, cerebrospinal fluid; ds, double-stranded; IFN, interferon; IL, interleukin; lpr, lymphoproliferation; M-CSF, macrophage colony-stimulating factor; MIF, macrophage migration inhibitory factor; MRL, Murphy Roths Large; NMDAR, N-methyl-D-aspartate receptor; sIL-6R, soluble IL-6 receptor; Sm, Smith; TNF, tumor necrosis factor; TWEAK, TNF-like weak inducer of apoptosis.

\subsubsection{Cytokines}

As it is not necessary that they pass the BBB to regulate neural function, cytokines and chemokines are critical early factors involved in behavioral defects [151]. The role of several cytokines in behavioral disturbances in MRL/lpr mice is supported by numerous studies (see [36]). More specifically, the early dysregulation of cytokine production, especially IL-1, IL-2, IL-6, and tumor necrosis factor (TNF) $\alpha$, corresponds to the onset of symptoms of depressive-like behavior, such as anhedonia and behavioral despair. Interestingly, anhedonia is ameliorated by cyclophosphamide, which suppresses the typically early and significant rise of IL-6, and can be replicated by exogenous IL-6 [58]. Furthermore, high levels of proinflammatory cytokines may also impair the function of the BBB and, thus, may be permissive to the deleterious effects of certain autoAbs and lymphocytes. 
In MRL/lpr mice, the CNS actively responds to the systemic production of several cytokines, as an upregulation of adhesion molecule expression is observed in the brain of diseased mice $[129,152]$. Upregulated in the peripheral blood of MRL/lpr mice, TNF $\alpha, \mathrm{IL}-1 \alpha$, and IL-1 $\beta$ are able to diffuse into the CSF and brain parenchyma $[153,154]$ where they increase the expression of ICAM- 1 and VCAM-1, leading to the recruitment of immune cells and subsequently to damage by either direct cytotoxicity or exacerbation of neuroinflammation. As suggested by the observation that inhibition of ICAM-1 in MRL/lpr mice prevents peripheral nerve damage, inhibiting cell adhesion molecule expression in NPSLE could be a promising therapeutic option. However, this line of treatment did not reduce infiltration to the choroid plexus (CP) [155], indicating that, though potentially beneficial, this therapy alone is not sufficient to allow complete resolution of NPSLE signs.

Of the various cytokines suspected to be involved in NPSLE pathogenesis, we make special mention the possible role of macrophage colony-stimulating factor (MIF), which is a proinflammatory cytokine displaying multifunctional properties. Operative in innate and adapted immunity [156,157], it plays an important role in regulating macrophage effector functions and $\mathrm{T}$ cell division [158]. MIF has moreover been highlighted in different structures of the CNS (e.g., hippocampus, cortex, cerebellum, pons) $[159,160]$. Its implication in the pathogenesis of many autoimmune/inflammatory diseases (e.g., multiple sclerosis (MS), Guillain Barré syndrome) is quite well described both in experimental and clinical studies [161-163]. MIF contributes also, with sex-specific regulation, to the emergence of depression and psychiatric disorders, likely via the dysregulation of the hypothalamic-pituitary-adrenal (HPA) axis and glucocorticoid secretion [164,165]. MIF is upregulated in SLE patients, where its level correlates positively with disease progression [166], as well as in MRL/lpr mice [146]. Moreover, the deletion of the MIF gene protects MRL/lpr mice from renal and skin manifestations of the disease [167] and reduces depressive symptoms in C57BL/6 mice [164]. Even more, as specific inhibitors of MIF attenuate the clinical course of SLE, therapeutic antagonism of MIF may be investigated as an opportunity for targeted therapy [167]. All these data, as well as the fact that MIF is also involved in autophagy [166], emphasize the important role played by MIF in the effector pathways of immune-mediated inflammatory damage both in SLE patients and murine lupus models $[146,166,168-170]$. They also point to its potential therapeutic use for treating NPSLE. In agreement with this hypothesis, an immunomodulatory peptide, hCDR1, which reduces NPSLE-like symptoms in lupus-prone mice [171], has been found to act on the MIF pathway by reducing its overexpression in the hippocampus [172]. Unfortunately, the effects of MIF and its inhibitors have not yet been further investigated in human NPSLE.

\subsubsection{Peripheral Immune Cell Infiltration}

Some years ago, the discovery of lymphatic vessels within the dura mater surrounding the brain provoked the dismissal of the existence of CNS immune privilege [173-175]. Regarding SLE and NPSLE, the access of peripheral immune cells, of which the best studied are lymphocytes, to the CNS through the $\mathrm{CP}$ has now been demonstrated in MRL/lpr mice [22]. Indeed, $\mathrm{CD}^{+} \mathrm{T}$ cells are detected in various areas of the MRL/lpr brain (e.g., ventricles, $\mathrm{CP}$, interhemispheric fissure, hippocampus, meninges, stria medullaris, cerebellar parenchyma), while $\mathrm{CD} 19^{+} \mathrm{B}$ cells are only found in the $\mathrm{CP}$ and the interhemispheric fissure [176]. Among the $\mathrm{CD}^{+} \mathrm{T}$ cells, brain parenchyma is largely infiltrated by inactive $\mathrm{CD} 8^{+} \mathrm{T}$ cells [177], while, in the $\mathrm{CP}$, the larger fraction of infiltrating cells are effector $\mathrm{CD}^{+} \mathrm{T}$ cells, which were further identified as $\mathrm{T}$ follicular helper (Tfh) cells [73]. Whereas a specific $\mathrm{Tfh}$ subset promotes $\mathrm{B}$ cell differentiation in the $\mathrm{CP}, \mathrm{CD}^{+}$cells are probably responsible for the increased production of proinflammatory cytokines upon detection of brain-derived self-antigens, leading to the recruitment of other immune cells and parenchymal infiltration [178]. Deletion of the $\mathrm{CD} 4^{+} \mathrm{T}$ cell phenotype has proven to be a successful therapy in mice developing CNS disease, indicating that targeting this cell phenotype might be an approach for treating NPSLE [179]. Unfortunately, this therapeutical option induces deleterious effects in other organs, probably as a result of the deletion of $\mathrm{CD}^{+} \mathrm{T}$ regulatory cells, a cell phenotype that attenuates inflammation [180]. 


\subsubsection{Glial Cells}

Although poorly explored and not well understood, the role of glial cells, the "sentinels of the brain", is expected to be central during the neuroinflammatory process of lupus [84]. Some authors reported the upregulation of ionized calcium binding adaptor molecule 1 (lba1; a microglia/macrophage-specific calcium-binding protein) and of CD68 (glycoprotein expressed by macrophages) in microglia of lupus-prone mice $[43,44]$. When activated, these cells express proinflammatory molecules and, as mentioned below, perform "synaptic pruning" [43]. Moreover, they probably incur damage by yet unidentified mechanisms. On the other hand, astrocytes are also activated during the disease, as evidenced by elevated astrogliosis in MRL/lpr mouse brain [181]. Further investigations focusing on the function of these cells in the pathogenic mechanisms of NPSLE are needed to better understand their precise role.

\subsection{Hippocampus as the Possible Primary Target of Neuroinflammatory Lupus}

NP symptoms observed in mouse models of lupus are commonly attributed to the dysfunction of the hippocampus, an observation also seen in human patients in whom reduced volumes of the hippocampal CA1 and CA4 regions have been associated with worse cognitive performances [182]. Accordingly, hippocampal neurons in MRL/lpr mice show signs of degeneration when stained by Fluoro-Jade B [153] that are backed by increased levels of proinflammatory cytokines (e.g., IFN- $\gamma$, IL-1 $\beta$, IL-6). Nonetheless, the concomitant presence of anti-inflammatory and immunomodulatory cytokines, for example, IL-10, highlights the complexity of the inflammatory context that occurs in the brains of these mice. In a comparable line, the simultaneous dysregulated production of both proinflammatory and anti-inflammatory cytokines has also been observed in SLE patients at the periphery [183]. This apparently common immunopathogenic aspect strengthens even more the immunopathogenic relevance of the murine models of lupus used to approach human SLE.

Several important properties of the hippocampus may explain both the neuroinflammatory and neurodegenerative processes affecting this cerebral structure during lupus disease. Firstly, the hippocampus is located next to the $\mathrm{CP}$ that, in addition to the meninges, as already pointed out above, is a common site of immune peripheral infiltration [176]. Furthermore, immunohistochemistry techniques have revealed that some peripheral immune cells infiltrate the hippocampus itself, homing in on structures that are much beyond their initial site of penetration. Thus, hippocampal proximity to immune infiltration sites could partially explain the susceptibility to NPSLE in this setting. Secondly, the hippocampus is a zone of prominent neurogenesis containing proliferating and maturing cell populations [184-186]. In MRL/lpr mice, replicating neuronal cells may display abnormal distribution throughout the CNS [187]. Moreover, the CSF of diseased mice evidences cytotoxicity toward proliferating neuronal cells [121,188]. Two general lines of hypotheses might explain why neurogenesis renders the hippocampus particularly sensitive to autoimmune diseases. One assumption is that newly forming neurons express surface markers different from those of differentiated neurons. Maturing neurons would express NMDAR [189] that is targeted by brain-reactive autoAbs. When it occurs, such binding elicits immediate excitotoxic neuronal death [190]. The second line of assumption questions the involvement of complement factors in neurogenesis and disease pathogenesis [191,192]. The complement components C1q and C3, produced by microglia, can be considered proinflammatory factors, as they play effector roles in a range of functions, including $\mathrm{T}$ cell activation and survival, chemotaxis, mast cell degranulation, and macrophage activation. Some of these activities participate in the synaptic loss and death of developing neurons [43,193]. In addition to neurogenesis, the hippocampus is a site of intense synaptic plasticity during ontogenesis and the learning phase [194]. Synaptic plasticity requires the trimming of specific neuronal circuits and reinforcement of others. Normally, this trimming, called "synaptic pruning", occurs during early fetal development and adolescence in humans (corresponding to 4 weeks post-natally in mice), but it can also be observed during adulthood [195]. Synaptic pruning is performed by microglia in the CNS [196] and also depends on complement factors [194]. Its overactivation results in injury in NPSLE [43]. 
Although further research is needed, this observation suggests that some zones of higher synaptic plasticity where new neuronal circuits are developing, for instance, in the hippocampus [195], could be particularly sensitive to autoimmune dysfunction. Overall, treatments promoting hippocampal neurogenesis and inhibiting the complement cascade might be regarded as promising therapeutic approaches against NPSLE [193,197,198].

Though the hippocampus seems to be centrally involved in NPSLE, other cerebral areas are affected in this disease, such as the cortex [199], the paraventricular nucleus (PVN) [39,193,200,201], the cerebellum [130], and probably a few others. For example, damage to the PVN alters the sucrose preference behavior $[58,60]$ and increases anxiety. PVN damages are also linked to systemic inflammation as excessive proinflammatory cytokines inhibit the negative feedback of the HPA axis, increase the permeability of the BBB, and disturb the glutamatergic balance [200,202]. At this stage, however, the mechanisms underlying these processes are not clear.

\subsection{Potential Mechanisms of Neuroinflammation in NPSLE}

In lupus-prone mice, different studies using TUNEL and Fluoro-Jade staining have reported neurodegeneration and apoptosis phenomena in the hippocampus, the PVN, and the cortex $[153,193,201,203,204]$. Today, a causal relationship between such damages and CNS exposure to autoAbs is fairly well documented, and the anti-NMDAR autoAbs are of special interest in NPSLE. These Abs specifically bind the NMDAR and lock it in an open position, leading to the uncontrolled entry of calcium ions into the cell. This passage eventually causes neuronal cell death through a mechanism known as "excitotoxicity" [190] (Figure 3).

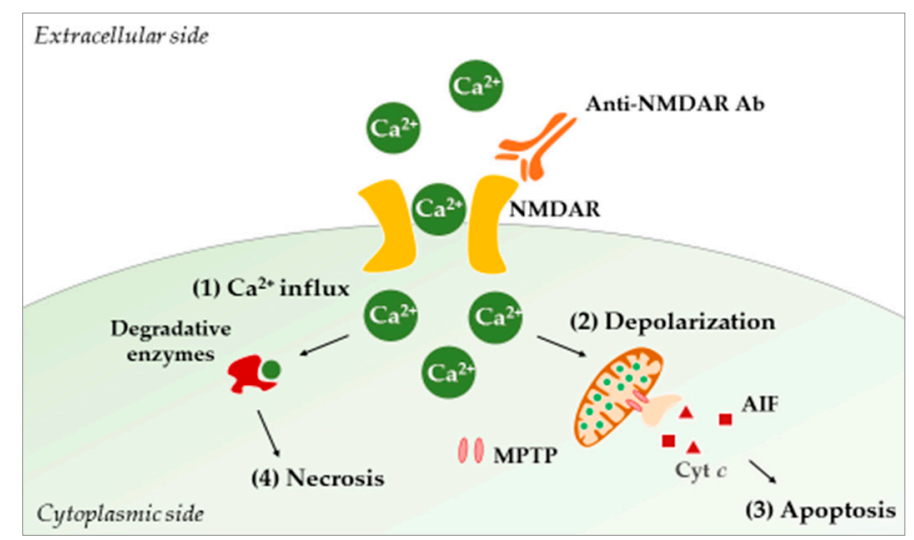

Figure 3. Acute excitotoxicity in NPSLE. The binding of anti-NMDAR Abs to NMDAR allows the free entry of calcium ions (1). Intracellularly, the ions are taken up by mitochondria in order to buffer incoming calcium, leading to increased cellular respiration and ROS production. Concomitant with the increase in calcium concentration, the mitochondrial membrane potential collapses, and MPTPs open (2). Consequently, proapoptotic molecules (e.g., Cyt c, AIF) are released, and apoptosis (controlled neuronal death) occurs (3). On the other hand, calcium can activate cytosolic enzymes (e.g., phospholipases, proteases, endonucleases) that will damage neurons intracellularly, leading to necrosis (4). Abbreviations: Ab, antibody; AIF, apoptosis-inducing factor; Cyt c, cytochrome $c$; MPTP, mitochondrial permeability transition pore; NMDAR, N-methyl-D-aspartate receptor; ROS, reactive oxygen species.

Of interest is excitotoxicity-related dysfunction, such as calcium overload in mitochondria, as it can result in dendrite degeneration [205]. This process could explain how long-term excitotoxicity may lead not only to neuronal death but also to dendritic spine degeneration and retraction [206] in NPSLE. Neuronal damage can also be induced by these same Abs through the overactivation of the already mentioned mechanism of synaptic pruning [43]. Here, anti-NMDAR autoAbs present on the surface of neurons are recognized by the complement factor $\mathrm{C} 1 \mathrm{q}$ [44]. This binding leads to the recruitment 
of other complement proteins and activation of the classical complement pathway that results in the deposition of the $\mathrm{C} 3 \mathrm{~b}$ complement factor on the neuronal target surface. In turn, $\mathrm{C} 3 \mathrm{~b}$ deposits are recognized by the $\mathrm{CD} 11 \mathrm{~b}$ receptor displayed by microglia. Upon activation of the $\mathrm{CD} 11 \mathrm{~b}$ receptor, microglia might engulf Ab-tagged structures, removing parts of the neuron [207] (Figure 4).

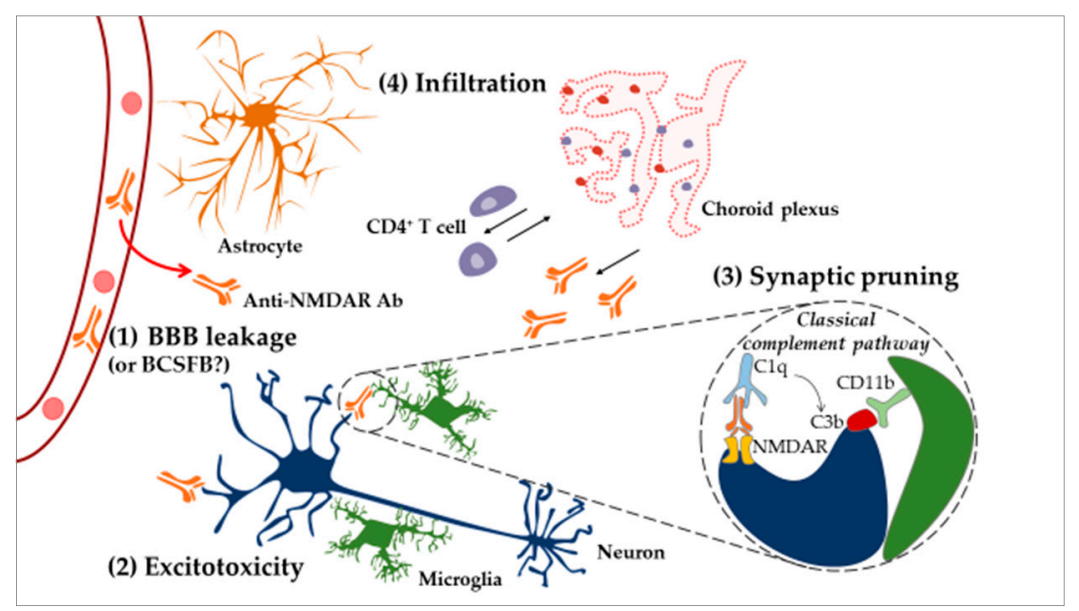

Figure 4. Neuroinflammatory model of NPSLE. In the CNS, under normal physiological conditions, microglial cells act as resident immune cells of the CNS and notably eliminate apoptotic cells. Systemic inflammation renders the BBB permeable to circulating inflammatory factors, for example, certain cytokines and autoAbs (e.g., anti-NMDAR) (1). After penetration into the brain, anti-NMDAR Abs can induce apoptotic death of neurons through the process of "excitotoxicity" (2). On the other hand, microglial cells can eliminate dendritic spines (the anatomical location of synapses) through a mechanism called "synaptic pruning" (3). Hypothetically, anti-neuronal autoAbs bind neuronal antigens recognized by the complement factor $\mathrm{C} 1 \mathrm{q}$ (synthetized by the CNS), leading to the production of C3b. Dendritic processes displaying $\mathrm{C} 3 \mathrm{~b}$ are recognized and phagocytosed by microglia. Furthermore, CNS cells activated following BBB's leakage upregulate ICAM-1 and VCAM-1 and modulate cytokine expression, resulting in the recruitment of peripheral immune cells (4). CD4 ${ }^{+} \mathrm{T}$ cells infiltrate the $\mathrm{CP}$ and the brain parenchyma, while $\mathrm{CD} 19^{+} \mathrm{B}$ cells are only found in the $\mathrm{CP}$. This suggests that $\mathrm{CD} 4^{+} \mathrm{T}$ cells might sample the brain environment in the parenchyma and activate $\mathrm{CD} 19^{+} \mathrm{B}$ cells in the $\mathrm{CP}$, leading to the production of Abs that circulate into the CSF. Abbreviations: Ab, antibody; BBB, blood-brain barrier; BCSFB, blood-cerebrospinal-fluid barrier; CNS, central nervous system; CP, choroid plexus; CSF, cerebrospinal fluid; ICAM-1, intercellular adhesion molecule-1; NMDAR, N-methyl-D-aspartate receptor; VCAM, vascular cell adhesion protein 1 .

The mechanism highlighted above is supported by experimental data evidencing that in lupus-like disease, neurons not only die, as noted previously, but also lose their dendritic processes $[44,45,204]$. The fact that defective synaptic pruning can be stopped by a depletion of microglia or by suppression of C1q [44] or C3 [197] components further corroborates such a mechanism. Interestingly, deletion of the alternative complement pathway could reduce CNS damage [208] but it remains unclear whether the attenuation in brain pathology is related to the reduction in systemic inflammation or if it is brain-specific. It is also unknown whether brain-reactive Abs reach the brain by diffusion through the disrupted BBB [209] or if they are produced intrathecally by infiltrating immune cells that home in on the brain. The presence of plasma cells in the CP suggests that, at least in part, Abs could be produced locally [176].

As indicated above, in MRL/lpr mice, a compromised BBB may allow for the diffusion, into the brain, of molecules present in the systemic circulation $[150,210]$ (Figure 4). It remains to clarify how a leakage in the BBB appears in MRL/lpr mice, however. According to some authors, excessive systemic signaling by circulating cytokines and complement factors could induce a process of controlled cell death (apoptosis) of ECs of the CNS vasculature, thus rendering the BBB leaky $[209,211]$. In this context, 
particular reference can be made to the TNF-like weak inducer of apoptosis (TWEAK)/fibroblast growth factor-inducible 14 (Fn14) pathway, which has been identified as the potential culprit of the breach of the BBB $[150,181,212]$. TWEAK is increased in the cerebral cortices of MRL/lpr mice. Moreover, as compared to MRL/lpr mice, MRL/lpr mice deficient for this pathway perform better in tests of cognition and are less depressed [150]. They also display reduced levels of CSF Igs, decreased peripheral immune cell infiltration, less complement deposition, impaired inducible nitric oxide synthase (iNOS) production, as well as reduced neuronal death [181]. Conversely, intracerebroventricular injection of Fn14 has the opposite effect (e.g., depression-like behavior, learning/memory deficits, macrophage/microglia activation, increased brain cell apoptosis, and astrogliosis) [212]. Consequently, this pathway may be considered as an important target for NPSLE modulation, as it could prevent the initial autoAbs and other effector molecules from penetrating the CNS.

A major question concerning how (and if) brain antigen-specific plasmocytes do mature in NPLSE remains open. An interesting hypothesis involving Tfh cells and generation of ectopic lymphoid structures in the CNS has been proposed and was brought forward with respect to MS [213]. In MS, B cells simultaneously exchange between the CNS and the deep cervical lymph nodes, where they mature into Ab-secreting plasmocytes with the help of local Tfh cells without the need to form ectopic lymphoid structures in the brain [214]. As no ectopic lymphoid structures have been reported in brain parenchyma during NPSLE yet, it is likely that the latter MS mechanism of B cell activation occurs also in NPSLE. It should be noted, however, that Tfh cells are found in the CP of MRL/lpr mice, suggesting that $\mathrm{B}$ cells could continue their activation in this structure as well [73].

Even though the precise sequence of neuroinflammatory processes in NPSLE is not fully elucidated, the current results strongly support a determining role of brain-reactive autoAbs. In the CNS, these autoAbs trigger proinflammatory responses by primed CNS cells, which leads to the recruitment of peripheral immune factors and induces further damage (Figure 4).

\subsection{Is NPSLE a Primarily CNS Disease?}

The model of "CNS primarily disease" for NPSLE states that, in MRL/lpr mice, NP events arise due to CNS intrinsic mechanisms. It has been shown that bone marrow transfer from young healthy $\mathrm{MRL}^{+/+}$mice to young (still healthy) MRL/lpr mice could not save the NP phenotype of the recipient mice, leading to the conclusion that systemic inflammation might effectively be dispensable for the emergence of these symptoms [215]. In good agreement with these results, the depletion of B cells in MRL/lpr mice at the age of 14 weeks does not suppress the NPSLE phenotype [216]. Since MRL ${ }^{+/+}$ and MRL/lpr mice differ in one fundamental aspect, which is the presence of a Fas gene mutation leading to loss of lymphocyte selection [41], the results obtained by the authors could be explained according to two possible lines of thought: either the Fas gene is responsible for the NP symptoms in MRL/lpr mice, or the activated systemic inflammation primes or induces damage in the CNS early in life and persists through life. The first hypothesis would exclude systemic inflammation as the culprit of NP disease.

An opposing comprehensive study showed that most of the behavioral and neurodegenerative symptoms arising in MRL/lpr mice are due to the systemic inflammation and not to the lpr mutation [200]. This study compared an MRL/lpr mouse strain that spontaneously displays an attenuated autoimmune profile and yet still carries the lpr mutation (stock \#0006825; Jackson Laboratory) to the original MRL/lpr mouse strain (stock \#000485; Jackson Laboratory). This research found that mice with an attenuated disease do not exhibit the vast majority of NPSLE-like symptoms. At last, a study conducted in patients refractory to standard therapy proposed that hematopoietic stem cell transplantation (HSCT) might be proposed as a therapeutic option $[217,218]$. Interestingly, a remission in NP symptoms has been observed in some cases $[219,220]$, confirming the relation between systemic inflammation and NPSLE symptoms. 
Another argument mitigating the hypothesis of "CNS primarily disease" has been evoked with the demonstration that production of type I IFNs, which are produced systemically during the course of the lupus disease [221], prime microglia for damage in lupus-prone mice. Mice deficient for IFN- $\alpha / \beta$ receptor (IFNAR) are protected from the damaging effects of synaptic pruning [43]. Furthermore, NP symptoms appear early in the life of MRL/lpr mice. For example, depression-like symptoms can be observed at as early as 8 weeks of age in MRL/lpr mice. This was the age that Stock et al. performed the adoptive bone marrow transfer [215]. It is an important point because the autoimmune processes could have had negative effects on the CNS in these mice prior to the bone marrow transfer. Indeed, proinflammatory factors are increased systemically early in the life of MRL/lpr mice [222], and damage by anti-NMDAR Abs lasts even after their removal [45]. Most importantly, it has been shown by two separate studies that the treatment of systemic inflammation attenuates brain damage in lupus-prone mice $[223,224]$. Another point to consider in this assumption is the effect of maternal autoAbs on the fetus. Some of the behavioral deficits might be difficult to attribute to the systemic inflammation that develops with age, because the fetus could be affected in utero and some specific behavioral deficits could be already present at birth $[55,199]$. More specifically, it has been shown that, when pregnant mice were immunized against NMDAR or exposed to human anti-NMDAR Abs, their pups developed thinner cortical layers and performed worse in cognitive tasks, showing how the fetus can be affected by the autoimmune status of the mother [199]. In this context, however, it should be noted that the MRL/lpr model, like all experimental models, has its own pitfalls. NPSLE patients could have a genetic CNS intrinsic predisposition to develop NP symptoms, which would require further study on specific gene candidates and additional experiments in an NPSLE-specific mouse model.

In conclusion, even though some behavioral symptoms appear to be related to the Fas mutation in MRL/lpr mice, most of these dysfunctions seem to be rather associated with systemic inflammation.

\section{Therapeutic Approach to NPSLE}

\subsection{Current Treatments}

The treatment of NPSLE is currently empirical and symptomatic and remains mainly palliative and nonspecific. Two general therapeutic approaches are distinguished, i.e., anti-ischemic and anti-inflammatory, both respectively stemming from the two presumed mechanisms of NPSLE pathogenesis, i.e., vascular/thrombotic and inflammatory [11].

State-of-the-art therapeutic strategies for NPSLE have been recently reviewed in great detail by Magro-Checa et al. [225] and Hanly et al. [11]. This aspect is not discussed in detail here. Nevertheless, we would like to stress the importance of the prompt management of NP symptoms in SLE patients.

Due to an absence of a "gold standard marker" in NPSLE diagnosis, attribution of NP symptoms to SLE represents a clinical challenge. Without any objective biomarkers, diagnosis solely relies on the exclusion of other potential causes (e.g., infections, hormonal/metabolic dysfunctions, medication-related adverse-effects). In the case of "confirmed" NPSLE diagnosis, therapy should be individualized to each specific patient, and the strategy of choice will depend on major symptoms and their severity. For example, patients presenting with seizures are administered anticonvulsants, those suffering from psychosis are treated with antipsychotics, depression is medicated by antidepressants, and headaches with analgesics or nonsteroidal anti-inflammatory drugs (NSAIDs) [226-228]. If symptoms are severe, specific and sometimes aggressive treatments are required [225].

In clinical practice, depending on the suspected underlying pathophysiological processes, therapy is directed at the prevention of ischemic/thrombotic events or at inflammation. Focal symptoms that arise due to the damage or blockage of arteries supplying the brain with oxygen and nutrients are addressed with anti-ischemic therapies, such as anticoagulants and antiplatelets. In the case of diffuse symptoms, which arise due to inflammation, an immunosuppressive therapy is primarily warranted, alone or in combination with anti-inflammatory medication (e.g., corticoids, cyclophosphamide) [225]. The efficacy of cyclophosphamide in treating NPSLE-like disease has been confirmed in MRL/lpr 
mice [223], thus indicating that novel therapies evaluated in this murine strain might be beneficial in human patients as well (Table 3).

Table 3. Some therapeutic molecules acting in the brain and tested in lupus-prone murine models.

\begin{tabular}{|c|c|c|c|}
\hline Therapeutic Molecule & Molecular Target & Neuroinflammatory Process & Reference \\
\hline Crry-Ig & C3 convertase & $\begin{array}{c}\text { Complement deposition } \\
\text { Apoptosis } \\
\text { Neurodegeneration } \\
\text { Cytokine production } \\
\text { Adhesion molecule expression }\end{array}$ & {$[193,197]$} \\
\hline Anti-ICAM-1 Ab & ICAM-1 & Sciatic nerve conductivity & [155] \\
\hline Anti-CD4 Ab & $\mathrm{CD}^{+} \mathrm{T}$ cells & $\begin{array}{l}\text { Immune cell infiltration } \\
\text { Inflammation of the CP }\end{array}$ & [179] \\
\hline Cyclophosphamide & Immune cell dsDNA & Synaptic pruning & [223] \\
\hline BI-BTK-1 & BTK & Immune cell infiltration & [224] \\
\hline GW2580 & CSF-1R & Cytokine expression & [229] \\
\hline PLX5622 & CSF-1R & Synaptic pruning & [44] \\
\hline Captopril & $\mathrm{ACE}$ & $\begin{array}{l}\text { Microglial activation } \\
\text { Synaptic pruning }\end{array}$ & [44] \\
\hline hCDR1 peptide/Edratide & Anti-dsDNA Ab & $\begin{array}{l}\text { Inhibition of neurogenesis } \\
\text { Complement deposition } \\
\text { Immune cell infiltration } \\
\text { Neurodegeneration }\end{array}$ & {$[171,198]$} \\
\hline $\begin{array}{l}\text { FTY720/Fingolimod } \\
\text { (Gilenya) }\end{array}$ & $\mathrm{S} 1 \mathrm{P}$ receptor & $\begin{array}{c}\text { BBB leakage } \\
\text { Immune cell infiltration } \\
\text { Cytokine production } \\
\text { Neurodegeneration }\end{array}$ & {$[230,231]$} \\
\hline P140 peptide/Lupuzor & HSPA8 & CMA regulation & [85] \\
\hline
\end{tabular}

Abbreviations: Ab, antibody; ACE, angiotensin converting enzyme; BBB, blood-brain barrier; BTK, Bruton's tyrosine kinase; $\mathrm{CMA}$, chaperone-mediated autophagy; $\mathrm{CP}$, choroid plexus; crry, complement regulator complement receptor 1-related gene/protein-y; CSF-1R, colony stimulating factor 1 receptor; ds, double-stranded; HSPA8, heat shock protein A8; ICAM-1, intercellular adhesion molecule; Ig, immunoglobulin; S1P, sphingosine-1-phosphate.

\subsection{A Potential Therapeutic Option: The Hypothesis of Autophagy}

Autophagy (from Ancient Greek, "self-devouring") is a vital, finely regulated intracellular process that results in the engulfment and destruction of self-components. Its main purpose is the generation of energy during periods of fasting and destruction of faulty cytoplasmic proteins and organelles [232-234]. Three major types of autophagy coexist, namely, macroautophagy (the best studied at present and which is negatively regulated by mechanistic target of rapamycin (mTOR)) [235]; microautophagy, which directly engulfs cytosolic material into lysosomes via the formation of characteristic invaginations of the lysosomal membrane [236]; and chaperone-mediated autophagy (CMA), in which an HSPA8/HSC70-containing complex recognizes proteins with a KFERQ-like motif [237].

Increasing evidence suggests autophagy's important role in both innate and adaptative immunity [238], and thereby its influence on the pathogenesis of inflammatory diseases (see [239]). Autophagy is particularly involved in inflammation by modulating and controlling the development, homeostasis, and survival of inflammatory cells, including B and T lymphocytes. In general, proinflammatory signals and cytokines induce autophagy, while autophagy itself can either increase or reduce proinflammatory cytokine secretion depending on the cellular and inflammatory context (see [240] for an extensive review of the question).

Altered autophagy is found in systemic manifestations of murine SLE [241] and other neuroinflammatory diseases, such as MS and experimental autoimmune encephalomyelitis, an experimental model of MS [85,242-245]. In these settings, upregulation of the protein kinase mTOR has been described. Indeed, treatment with rapamycin — an immunosuppressant also known as sirolimus-that inhibits mTOR and, thus, stimulates macroautophagy [246], ameliorates some 
clinical and histological signs of the disease $[247,248]$. Interestingly, comparable beneficial effects were reported two decades ago in murine SLE [249] and, more recently, also in human SLE [250]. Overall, these data support the view that molecules exerting immunomodulatory effects, and particularly modulating autophagy pathways, should be further investigated and exploited in the therapy of several autoimmune disorders [251].

Autophagy in microglia has been implicated in the development of neuroinflammatory and neurodegenerative diseases [252]. More particularly, a role for microglial autophagy in synaptic pruning and maturation of neuronal connections during development and in the formation of social behaviors has been described recently [253], bringing new insights to NPSLE. Of important note, synaptic pruning in microglia is dependent on microtubule-associated protein light chain 3 (LC3)-associated phagocytosis (LAP) [254]. Dysfunction of LAP is thought to be important in the development of SLE [255], as LAP ablation in the myeloid cell lineage (including microglia) renders mice prone to developing lupus, whereas deletion of macroautophagy itself failed to increase lupus-like symptoms [241]. In the brain of lupus-prone mice, accumulation of neuronal material has been reported in microglia, suggesting that LAP might also be deficient [43]. Concomitantly, elevated levels of autophagy-related proteins (BECLIN-1, LC3, sequestosome-1 (SQSTM1)) have been observed in the brain of diseased MRL/lpr mice, pointing to an increase of autophagy initiation/LAPosome formation with a defect in their degradation rate [256]. On the other hand, and as described above, treatment of SLE with activators of autophagy may lead to better outcomes [249]. The LAP axis is a noncanonical form of autophagy, besides other canonical processes of autophagy, which may be specifically involved in lupus-like disease [241]. To summarize, we hypothesize that NPSLE could greatly benefit from a therapy specifically targeting the formation of LAPosomes in order to increase dendrite arborization and reduce synaptic pruning.

As autophagy can have both beneficial [257] and deleterious [258] effects depending on the disease context [252], we should be very cautious when interpreting the global effects of autophagy-targeting treatment because it could be cell- and time-specific. We already observed that the aberrant autophagy activity (downregulation or hyperactivation) that occurs in pathological settings is not a general feature that equally affects all organs or tissues of any individual [259]. On the contrary, dysregulation can greatly differ from one organ to another, a conclusion also underpinning several autoimmune or non-autoimmune indications [85]. Similarly, it would be fair to emphasize the possible existence of a dichotomic regulation of autophagy (CNS vs. periphery) during SLE. Then, reduction of autophagy should happen at the periphery, which benefits from mTOR inhibitors (e.g., rapamycin), whereas the upregulation of autophagy should occur in the CNS, which would benefit from autophagy inhibitors (e.g., mTOR agonists). If the hypothesis is correct, SLE patients treated with mTOR inhibitors should be very carefully monitored for NPSLE.

We are currently performing behavioral evaluations on MRL/lpr mice administered with a peptide targeting autophagy, particularly CMA, in lupus mice and likely SLE patients also [260,261]. This peptide, called P140, encompasses residues of the U1-70K spliceosomal protein and contains a phosphoserine residue at position 140, hence its name [262]. Our investigations provide promising data for treating SLE patients [263] and possibly also patients with NPSLE: we observed beneficial effects of the peptide on spatial alternation deficits in 17-week-old female MRL/lpr mice [84,85]. Yet, it remains to be determined if P140 can indeed help preserve neuron dendrite arborization in experimental MRL/lpr mice.

\section{Conclusive Remarks and Perspectives}

NPSLE acts as a convincing example of generalized inflammation and autoimmunity leading to CNS damage with behavioral outcomes. However, this is not a unique case of peripheral immune processes propagating at the CNS level and inducing severe disturbances [264]. For example, the assumption that systemic overexpression of IL-6 may contribute to BBB failure and the development of amyotrophic lateral sclerosis has been formulated [265]. It has also been observed that systemic 
inflammation can induce emotional and cognitive impairments, called sickness behavior, which can resolve on its own. However, in severe cases, like sepsis, the damage can be permanent. This aspect has been extensively reviewed elsewhere [266].

Here, we propose that NPSLE-like disease developing, for example, in lupus-prone MRL/lpr mice, should be regarded as a model of choice for allowing the study of how systemic inflammation affects the brain. Neuroinflammatory mechanisms reported in these mice are comparable to those described in other chronic inflammatory diseases and sepsis. Therefore, they should not be overlooked.

Further research dealing with human NPSLE and murine models of NPSLE should help to better understand the pathophysiological events that trigger and sustain this strong form of lupus disease and allow the validation of useful NPSLE biomarkers. This includes studies based on neuroimaging and investigations aiming to identify serologic and CSF markers. This will be a fundamental step in planning future randomized control trials on the treatment of NPSLE.

\section{Ethics Statement}

Experimental protocols and animal care fulfilled EU regulations (European Council Directive 2013-118) and recommendations of the French national charter for ethics of animal experiments (articles R.214-87 to R.214-126 of the "Code rural et de la pêche maritime"; authorizations no. 04436.02 and no. 3603-2015120211275427v3). The MRI protocol was also approved by the local research institutional animal care and use committee on the ethics of animal experiments (CEEA 35). All efforts were made to minimize animal suffering and respect the 3Rs (Reduce, Refine, Replace).

Author Contributions: Conceptualization, C.P., S.M. and H.J.-D.; Methodology, S.P. and H.J.-D.; Formal analysis, M.B., C.P. and H.J.-D.; Investigation, M.B., C.P. and H.J.-D.; Writing-Original Draft, M.B., C.P., S.M. and H.J.-D.; Writing-Review \& Editing, M.B., C.P., S.M. and H.J.-D.; Visualization, C.P., M.B. and H.J.-D.; Supervision, S.M. and H.J.-D.; Funding Acquisition, S.M.

Funding: This research received no external funding.

Acknowledgments: We are grateful to Nathalie Petit-Demoulière for help with animal care. We thank the Centre National de la Recherche Scientifique (CNRS, France), the University of Strasbourg, the Laboratory of Excellence Medalis (ANR-10-LABX-0034), the Initiative of Excellence (IdEx) Strasbourg University, the University of Strasbourg Institute for Advanced Study (USIAS), the Région Grand-Est, ImmuPharma Company, the TRANSAUTOPHAGY COST Action CA15138, and the Club francophone de l'autophagie (CFATG). M.B. is a recipient of a doctoral fellowship from the Région Grand Est and the LabEx Medalis.

Conflicts of Interest: The authors declare no conflict of interest.

\section{Abbreviations}

$\begin{array}{ll}\mathrm{Ab} & \text { Antibody } \\ \mathrm{ACR} & \text { American College of Rheumatology } \\ \mathrm{aPL} & \text { Antiphospholipid } \\ \mathrm{BBB} & \text { Blood-brain barrier } \\ \mathrm{BCSFB} & \text { Blood-cerebrospinal-fluid barrier } \\ \mathrm{BOLD} & \text { Blood oxygen level-dependent } \\ \mathrm{CD} & \text { Cluster of differentiation } \\ \mathrm{CMA} & \text { Chaperone-mediated autophagy } \\ \mathrm{CNS} & \text { Central nervous system } \\ \mathrm{CP} & \text { Choroid plexus } \\ \mathrm{CSF} & \text { Cerebrospinal fluid } \\ \mathrm{Cyt} c & \text { Cytochrome } c \\ \mathrm{dsDNA} & \text { Double stranded DNA } \\ \mathrm{DTI} & \text { Diffusion tensor imaging } \\ \mathrm{DWI} & \text { Diffusion-weighted imaging } \\ \text { ECs } & \text { Endothelial cells } \\ \text { Fas } / \text { APO-1/CD95 } & \text { Apoptosis stimulating fragment } \\ \mathrm{HPA} & \text { Hypothalamic-pituitary-adrenal } \\ \end{array}$




\begin{tabular}{|c|c|}
\hline HSCT & Hematopoietic stem cell transplantation \\
\hline HSPA8 & Heat shock $70-\mathrm{kD}$ protein $\mathrm{A} 8$ isoform 1 \\
\hline Iba1 & Ionized calcium binding adaptor molecule 1 \\
\hline ICAM-1 & Intercellular adhesion molecule 1 \\
\hline IFN & Interferon \\
\hline IFNAR & IFN- $\alpha / \beta$ receptor \\
\hline Ig & Immunoglobulin \\
\hline IL & Interleukin \\
\hline iNOS & Inducible nitric oxide synthase \\
\hline LAP & LC3-associated phagocytosis \\
\hline LC3 & Microtubule-associated protein light chain 3 \\
\hline lpr & Lymphoproliferation \\
\hline M-CSF & Macrophage colony-stimulating factor \\
\hline MIF & Macrophage migration inhibitory factor \\
\hline MPTP & Mitochondrial permeability transition pore \\
\hline MRA & Magnetic resonance angiography \\
\hline MRI & Magnetic resonance imaging \\
\hline MRL & Murphy Roths Large \\
\hline MRS & Magnetic resonance spectroscopy \\
\hline MS & Multiple sclerosis \\
\hline MTI & Magnetic transfer imaging \\
\hline mTOR & Mechanistic/mammalian target of rapamycin \\
\hline MTR & Magnetic transfer ratio \\
\hline NAA & $\mathrm{N}$-acetyl aspartate \\
\hline NMDAR & N-methyl-D-aspartate receptor \\
\hline NPSLE & Neuropsychiatric systemic lupus erythematosus \\
\hline NSAIDs & Non-steroid anti-inflammatory drugs \\
\hline NZW & New Zealand White \\
\hline NZB & New Zealand Black \\
\hline PAF & Paraformaldehyde \\
\hline RARE & Rapid acquisition with relaxation enhancement \\
\hline ROS & Reactive oxygen species \\
\hline SQSTM1/p62 & Sequestosome-1/p62 \\
\hline $\mathrm{T} 1$ & Longitudinal relaxation time \\
\hline $\mathrm{T} 2$ & Transverse relaxation time \\
\hline $\mathrm{TE}$ & Echo time \\
\hline Tfh & $\mathrm{T}$ follicular helper \\
\hline TNF & Tumor necrosis factor \\
\hline TR & Repetition time \\
\hline TWEAK & TNF-like weak inducer of apoptosis \\
\hline VCAM-1 & Vascular cell adhesion protein 1 \\
\hline vs. & versus \\
\hline
\end{tabular}

\section{References}

1. Suárez-Fueyo, A.; Bradley, S.J.; Tsokos, G.C. T cells in systemic lupus erythematosus. Curr. Opin. Immunol. 2016, 43, 32-38. [CrossRef] [PubMed]

2. Tsokos, G.C. Systemic lupus erythematosus. N. Engl. J. Med. 2011, 365, 2110-2121. [CrossRef] [PubMed]

3. O'Neill, S.; Cervera, R. Systemic lupus erythematosus. Best Pract. Res. Clin. Rheumatol. 2010, 24, 841-855. [CrossRef] [PubMed]

4. Rahman, A.; Isenberg, D.A. Systemic lupus erythematosus. N. Engl. J. Med. 2008, 358, 929-939. [CrossRef] [PubMed]

5. Bove, R. Autoimmune diseases and reproductive aging. Clin. Immunol. 2013, 149, 251-264. [CrossRef] [PubMed] 
6. Koga, M.; Kawasaki, A.; Ito, I.; Furuya, T.; Ohashi, J.; Kyogoku, C.; Ito, S.; Hayashi, T.; Matsumoto, I.; Kusaoi, M.; et al. Cumulative association of eight susceptibility genes with systemic lupus erythematosus in a Japanese female population. J. Hum. Genet. 2011, 56, 503-507. [CrossRef] [PubMed]

7. Rubtsov, A.V.; Rubtsova, K.; Kappler, J.W.; Marrack, P. Genetic and hormonal factors in female-biased autoimmunity. Autoimmun. Rev. 2010, 9, 494-498. [CrossRef] [PubMed]

8. Zandman-Goddard, G.; Solomon, M.; Rosman, Z.; Peeva, E.; Shoenfeld, Y. Environment and lupus-related diseases. Lupus 2012, 21, 241-250. [CrossRef] [PubMed]

9. Hanly, J.G.; Urowitz, M.B.; Su, L.; Bae, S.C.; Gordon, C.; Wallace, D.J.; Clarke, A.; Bernatsky, S.; Isenberg, D.; Rahman, A.; et al. Prospective analysis of neuropsychiatric events in an international disease inception cohort of patients with systemic lupus erythematosus. Ann. Rheum. Dis. 2010, 69, 529-535. [CrossRef] [PubMed]

10. Jeltsch-David, H.; Muller, S. Neuropsychiatric systemic lupus erythematosus: Pathogenesis and biomarkers. Nat. Rev. Neurol. 2014, 10, 579-596. [CrossRef] [PubMed]

11. Hanly, J.G.; Kozora, E.; Beyea, S.; Birnbaum, J. Nervous system disease in systemic lupus erythematosus: Current status and future directions. Arthritis Rheumatol. 2018. [CrossRef] [PubMed]

12. Monahan, R.C.; Beaart-van de Voorde, L.J.J.; Steup-Beekman, G.M.; Magro-Checa, C.; Huizinga, T.W.J.; Hoekman, J.; Kaptein, A.A. Neuropsychiatric symptoms in systemic lupus erythematosus: Impact on quality of life. Lupus 2017, 26, 1252-1259. [CrossRef] [PubMed]

13. Magro-Checa, C.; Beaart-van de Voorde, L.J.J.; Middelkoop, H.A.M.; Dane, M.L.; van der Wee, N.J.; van Buchem, M.A.; Huizinga, T.W.J.; Steup-Beekman, G.M. Outcomes of neuropsychiatric events in systemic lupus erythematosus based on clinical phenotypes; prospective data from the Leiden NP SLE cohort. Lupus 2017, 26, 543-551. [CrossRef] [PubMed]

14. Zirkzee, E.; Huizinga, T.; Bollen, E.; van Buchem, M.; Middelkoop, H.; van der Wee, N.; le Cessie, S.; Steup-Beekman, G. Mortality in neuropsychiatric systemic lupus erythematosus (NPSLE). Lupus 2014, 23, 31-38. [CrossRef] [PubMed]

15. ACR ad hoc committee The American College of Rheumatology nomenclature and case definitions for neuropsychiatric lupus syndromes. Arthritis Rheum. 1999, 42, 599-608. [CrossRef]

16. Hanly, J.G. Diagnosis and management of neuropsychiatric SLE. Nat. Rev. Rheumatol. 2014, 10, 338-347. [CrossRef] [PubMed]

17. Ainiala, H.; Loukkola, J.; Peltola, J.; Korpela, M.; Hietaharju, A. The prevalence of neuropsychiatric syndromes in systemic lupus erythematosus. Neurology 2001, 57, 496-500. [CrossRef] [PubMed]

18. Ainiala, H.; Hietaharju, A.; Loukkola, J.; Peltola, J.; Korpela, M.; Metsänoja, R.; Auvinen, A. Validity of the new American College of Rheumatology criteria for neuropsychiatric lupus syndromes: A population-based evaluation. Arthritis Rheum. 2001, 45, 419-423. [CrossRef]

19. Bortoluzzi, A.; Scirè, C.A.; Govoni, M. Attribution of neuropsychiatric manifestations to systemic lupus erythematosus. Front. Med. 2018, 5, 68. [CrossRef] [PubMed]

20. Zandman-Goddard, G.; Chapman, J.; Shoenfeld, Y. Autoantibodies involved in neuropsychiatric SLE and antiphospholipid syndrome. Semin. Arthritis Rheum. 2007, 36, 297-315. [CrossRef] [PubMed]

21. Leslie, B.; Crowe, S.F. Cognitive functioning in systemic lupus erythematosus: A meta-analysis. Lupus 2018, 27, 920-929. [CrossRef] [PubMed]

22. Gelb, S.; Stock, A.D.; Anzi, S.; Putterman, C.; Ben-Zvi, A. Mechanisms of neuropsychiatric lupus: The relative roles of the blood-cerebrospinal fluid barrier versus blood-brain barrier. J. Autoimmun. 2018, 91, 34-44. [CrossRef] [PubMed]

23. Gerosa, M.; Poletti, B.; Pregnolato, F.; Castellino, G.; Lafronza, A.; Silani, V.; Riboldi, P.; Meroni, P.L.; Merrill, J.T. Antiglutamate receptor antibodies and cognitive impairment in primary antiphospholipid syndrome and systemic lupus erythematosus. Front. Immunol. 2016, 7, 5. [CrossRef] [PubMed]

24. Ho, R.C.; Thiaghu, C.; Ong, H.; Lu, Y.; Ho, C.S.; Tam, W.W.; Zhang, M.W. A meta-analysis of serum and cerebrospinal fluid autoantibodies in neuropsychiatric systemic lupus erythematosus. Autoimmun. Rev. 2016, 15, 124-138. [CrossRef] [PubMed]

25. Dema, B.; Charles, N. Autoantibodies in SLE: Specificities, isotypes and receptors. Antibodies 2016, 5, 2. [CrossRef]

26. Hirohata, S.; Sakuma, Y.; Matsueda, Y.; Arinuma, Y.; Yanagida, T. Role of serum autoantibodies in blood brain barrier damages in neuropsychiatric systemic lupus erythematosus. Clin. Exp. Rheumatol. 2018. 
27. Matsueda, Y.; Arinuma, Y.; Nagai, T.; Hirohata, S. Elevation of serum anti-glucose-regulated protein 78 antibodies in neuropsychiatric systemic lupus erythematosus. Lupus Sci. Med. 2018, 5, e000281. [CrossRef] [PubMed]

28. de Boer, A.G.; Gaillard, P.J. Blood-brain barrier dysfunction and recovery. J. Neural Transm. 2006, 113, 455-462. [CrossRef] [PubMed]

29. Abbott, N.J.; Patabendige, A.A.K.; Dolman, D.E.M.; Yusof, S.R.; Begley, D.J. Structure and function of the blood-brain barrier. Neurobiol. Dis. 2010, 37, 13-25. [CrossRef] [PubMed]

30. Preston, J.E.; Joan Abbott, N.; Begley, D.J. Transcytosis of macromolecules at the blood-brain barrier. Adv. Pharmacol. 2014, 71, 147-163. [CrossRef] [PubMed]

31. Abbott, N.J.; Mendonça, L.L.F.; Dolman, D.E.M. The blood-brain barrier in systemic lupus erythematosus. Lupus 2003, 12, 908-915. [CrossRef] [PubMed]

32. McLean, B.N.; Miller, D.; Thompson, E.J. Oligoclonal banding of IgG in CSF, blood-brain barrier function, and MRI findings in patients with sarcoidosis, systemic lupus erythematosus, and Behçet's disease involving the nervous system. J. Neurol. Neurosurg. Psychiatry 1995, 58, 548-554. [CrossRef] [PubMed]

33. Sato, T.; Fujii, T.; Yokoyama, T.; Fujita, Y.; Imura, Y.; Yukawa, N.; Kawabata, D.; Nojima, T.; Ohmura, K.; Usui, T.; et al. Anti-U1 RNP antibodies in cerebrospinal fluid are associated with central neuropsychiatric manifestations in systemic lupus erythematosus and mixed connective tissue disease. Arthritis Rheum. 2010, 62, 3730-3740. [CrossRef] [PubMed]

34. Miller, D.H.; Buchanan, N.; Barker, G.; Morrissey, S.P.; Kendall, B.E.; Rudge, P.; Khamashta, M.; Hughes, G.R.; McDonald, W.I. Gadolinium-enhanced magnetic resonance imaging of the central nervous system in systemic lupus erythematosus. J. Neurol. 1992, 239, 460-464. [CrossRef] [PubMed]

35. Stock, A.D.; Gelb, S.; Pasternak, O.; Ben-Zvi, A.; Putterman, C. The blood brain barrier and neuropsychiatric lupus: New perspectives in light of advances in understanding the neuroimmune interface. Autoimmun. Rev. 2017, 16, 612-619. [CrossRef] [PubMed]

36. Gulinello, M.; Putterman, C. The MRL/lpr mouse strain as a model for neuropsychiatric systemic lupus erythematosus. J. Biomed. Biotechnol. 2011, 2011, 1-15. [CrossRef] [PubMed]

37. Perry, D.; Sang, A.; Yin, Y.; Zheng, Y.-Y.; Morel, L. Murine models of systemic lupus erythematosus. J. Biomed. Biotechnol. 2011, 2011, 1-19. [CrossRef] [PubMed]

38. Rekvig, O.P.; Putterman, C.; Casu, C.; Gao, H.-X.; Ghirardello, A.; Mortensen, E.S.; Tincani, A.; Doria, A. Autoantibodies in lupus: Culprits or passive bystanders? Autoimmun. Rev. 2012, 11, 596-603. [CrossRef] [PubMed]

39. Stanojcic, M.; Loheswaran, G.; Xu, L.; Hoffman, S.A.; Sakić, B. Intrathecal antibodies and brain damage in autoimmune MRL mice. Brain. Behav. Immun. 2010, 24, 289-297. [CrossRef] [PubMed]

40. Sidor, M.M.; Sakić, B.; Malinowski, P.M.; Ballok, D.A.; Oleschuk, C.J.; Macri, J. Elevated immunoglobulin levels in the cerebrospinal fluid from lupus-prone mice. J. Neuroimmunol. 2005, 165, 104-113. [CrossRef] [PubMed]

41. Jeltsch-David, H.; Muller, S. Neuropsychiatric systemic lupus erythematosus and cognitive dysfunction: The MRL-lpr mouse strain as a model. Autoimmun. Rev. 2014, 13, 963-973. [CrossRef] [PubMed]

42. Han, J.H.; Umiker, B.R.; Kazimirova, A.A.; Fray, M.; Korgaonkar, P.; Selsing, E.; Imanishi-Kari, T. Expression of an anti-RNA autoantibody in a mouse model of SLE increases neutrophil and monocyte numbers as well as IFN-I expression. Eur. J. Immunol. 2014, 44, 215-226. [CrossRef] [PubMed]

43. Bialas, A.R.; Presumey, J.; Das, A.; van der Poel, C.E.; Lapchak, P.H.; Mesin, L.; Victora, G.; Tsokos, G.C.; Mawrin, C.; Herbst, R.; et al. Microglia-dependent synapse loss in type I interferon-mediated lupus. Nature 2017, 546, 539-543. [CrossRef] [PubMed]

44. Nestor, J.; Arinuma, Y.; Huerta, T.S.; Kowal, C.; Nasiri, E.; Kello, N.; Fujieda, Y.; Bialas, A.; Hammond, T.; Sriram, U.; et al. Lupus antibodies induce behavioral changes mediated by microglia and blocked by ACE inhibitors. J. Exp. Med. 2018, 215, 2554-2566. [CrossRef] [PubMed]

45. Chang, E.H.; Volpe, B.T.; Mackay, M.; Aranow, C.; Watson, P.; Kowal, C.; Storbeck, J.; Mattis, P.; Berlin, R.; Chen, H.; et al. Selective impairment of spatial cognition caused by autoantibodies to the N-Methyl-D-aspartate receptor. EBioMedicine 2015, 2, 755-764. [CrossRef] [PubMed]

46. DeGiorgio, L.A.; Konstantinov, K.N.; Lee, S.C.; Hardin, J.A.; Volpe, B.T.; Diamond, B. A subset of lupus anti-DNA antibodies cross-reacts with the NR2 glutamate receptor in systemic lupus erythematosus. Nat. Med. 2001, 7, 1189-1193. [CrossRef] [PubMed] 
47. Frauenknecht, K.; Leukel, P.; Weiss, R.; von Pein, H.D.; Katzav, A.; Chapman, J.; Sommer, C.J. Decreased hippocampal cell proliferation in mice with experimental antiphospholipid syndrome. Brain Struct. Funct. 2018, 223, 3463-3471. [CrossRef] [PubMed]

48. Pikman, R.; Kivity, S.; Levy, Y.; Arango, M.-T.; Chapman, J.; Yonath, H.; Shoenfeld, Y.; Gofrit, S.G. Neuropsychiatric SLE: From animal model to human. Lupus 2017, 26, 470-477. [CrossRef] [PubMed]

49. Murphy, E.D.; Roths, J.B. A Y chromosome associated factor in strain BXSB producing accelerated autoimmunity and lymphoproliferation. Arthritis Rheum. 1979, 22, 1188-1194. [CrossRef] [PubMed]

50. Watson, M.L.; Rao, J.K.; Gilkeson, G.S.; Ruiz, P.; Eicher, E.M.; Pisetsky, D.S.; Matsuzawa, A.; Rochelle, J.M.; Seldin, M.F. Genetic analysis of MRL-lpr mice: Relationship of the Fas apoptosis gene to disease manifestations and renal disease-modifying loci. J. Exp. Med. 1992, 176, 1645-1656. [CrossRef] [PubMed]

51. Drappa, J.; Brot, N.; Elkon, K.B. The Fas protein is expressed at high levels on CD4+CD8+ thymocytes and activated mature lymphocytes in normal mice but not in the lupus-prone strain, MRL lpr/lpr. Proc. Natl. Acad. Sci. USA 1993, 90, 10340-10344. [CrossRef] [PubMed]

52. Theofilopoulos, A.N. Murine models of lupus. In Systemic Lupus Erythematosus; Lahita, R.G., Ed.; Churchill Livingstone: New York, NY, USA, 1992; pp. 121-194.

53. Deacon, R.M.J. Shallow water (paddling) variants of water maze tests in mice. J. Vis. Exp. 2013. [CrossRef] [PubMed]

54. Porsolt, R.D. Animal model of depression. Biomedicine 1979, 30, 139-140. [PubMed]

55. Sakić, B.; Szechtman, H.; Talangbayan, H.; Denburg, S.D.; Carbotte, R.M.; Denburg, J.A. Disturbed emotionality in autoimmune MRL-lpr mice. Physiol. Behav. 1994, 56, 609-617. [CrossRef]

56. Sakić, B.; Szechtman, H.; Keffer, M.; Talangbayan, H.; Stead, R.; Denburg, J.A. A behavioral profile of autoimmune lupus-prone MRL mice. Brain. Behav. Immun. 1992, 6, 265-285. [PubMed]

57. Gao, H.-X.; Sanders, E.; Tieng, A.T.; Putterman, C. Sex and autoantibody titers determine the development of neuropsychiatric manifestations in lupus-prone mice. J. Neuroimmunol. 2010, 229, 112-122. [CrossRef] [PubMed]

58. Sakić, B.; Szechtman, H.; Braciak, T.; Richards, C.; Gauldie, J.; Denburg, J.A. Reduced preference for sucrose in autoimmune mice: A possible role of interleukin-6. Brain Res. Bull. 1997, 44, 155-165. [CrossRef]

59. Ballok, D.A.; Earls, A.M.; Krasnik, C.; Hoffman, S.A.; Sakić, B. Autoimmune-induced damage of the midbrain dopaminergic system in lupus-prone mice. J. Neuroimmunol. 2004, 152, 83-97. [CrossRef] [PubMed]

60. Ballok, D.A.; Szechtman, H.; Sakić, B. Taste responsiveness and diet preference in autoimmune MRL mice. Behav. Brain Res. 2003, 140, 119-130. [CrossRef]

61. Sakić, B.; Denburg, J.A.; Denburg, S.D.; Szechtman, H. Blunted sensitivity to sucrose in autoimmune MRL-lpr mice: A curve-shift study. Brain Res. Bull. 1996, 41, 305-311. [CrossRef]

62. Szechtman, H.; Sakić, B.; Denburg, J.A. Behaviour of MRL mice: An animal model of disturbed behaviour in systemic autoimmune disease. Lupus 1997, 6, 223-229. [CrossRef] [PubMed]

63. Misslin, R.; Belzung, C.; Vogel, E. Behavioural validation of a light/dark choice procedure for testing anti-anxiety agents. Behav. Process. 1989, 18, 119-132. [CrossRef]

64. Pellow, S.; Chopin, P.; File, S.E.; Briley, M. Validation of open:closed arm entries in an elevated plus-maze as a measure of anxiety in the rat. J. Neurosci. Methods 1985, 14, 149-167. [CrossRef]

65. Pellow, S.; File, S.E. Anxiolytic and anxiogenic drug effects on exploratory activity in an elevated plus-maze: A novel test of anxiety in the rat. Pharmacol. Biochem. Behav. 1986, 24, 525-529. [CrossRef]

66. Gao, H.-X.; Campbell, S.R.; Cui, M.-H.; Zong, P.; Hwang, J.-H.; Gulinello, M.; Putterman, C. Depression is an early disease manifestation in lupus-prone MRL/lpr mice. J. Neuroimmunol. 2009, 207, 45-56. [CrossRef] [PubMed]

67. Nielsen, D.M.; Crnic, L.S. Elevated plus maze behavior, auditory startle response, and shock sensitivity in predisease and in early stage autoimmune disease MRL/lpr mice. Brain. Behav. Immun. 2002, 16, 46-61. [CrossRef] [PubMed]

68. Crawley, J.N. Exploratory behavior models of anxiety in mice. Neurosci. Biobehav. Rev. 1985, 9, 37-44. [CrossRef]

69. Simon, P.; Dupuis, R.; Costentin, J. Thigmotaxis as an index of anxiety in mice. Influence of dopaminergic transmissions. Behav. Brain Res. 1994, 61, 59-64. [CrossRef] 
70. Carola, V.; D'Olimpio, F.; Brunamonti, E.; Mangia, F.; Renzi, P. Evaluation of the elevated plus-maze and open-field tests for the assessment of anxiety-related behaviour in inbred mice. Behav. Brain Res. 2002, 134, 49-57. [CrossRef]

71. Archer, J. Rodent sex differences in emotional and related behavior. Behav. Biol. 1975, 14, 451-479. [CrossRef]

72. Donner, N.C.; Lowry, C.A. Sex differences in anxiety and emotional behavior. Pflugers Arch. 2013, 465, 601-626. [CrossRef] [PubMed]

73. Jain, S.; Stock, A.; Macian, F.; Putterman, C. A distinct T follicular helper cell subset infiltrates the brain in murine neuropsychiatric lupus. Front. Immunol. 2018, 9, 487. [CrossRef] [PubMed]

74. Stewart, S.; Cacucci, F.; Lever, C. Which memory task for my mouse? A systematic review of spatial memory performance in the Tg2576 Alzheimer's mouse model. J. Alzheimers Dis. JAD 2011, 26, 105-126. [CrossRef] [PubMed]

75. Ennaceur, A.; Neave, N.; Aggleton, J.P. Spontaneous object recognition and object location memory in rats: The effects of lesions in the cingulate cortices, the medial prefrontal cortex, the cingulum bundle and the fornix. Exp. Brain Res. 1997, 113, 509-519. [CrossRef] [PubMed]

76. Aggleton, J.P.; Nelson, A.J.D. Why do lesions in the rodent anterior thalamic nuclei cause such severe spatial deficits? Neurosci. Biobehav. Rev. 2015, 54, 131-144. [CrossRef] [PubMed]

77. Morris, R. Developments of a water-maze procedure for studying spatial learning in the rat. J. Neurosci. Methods 1984, 11, 47-60. [CrossRef]

78. Sakić, B.; Szechtman, H.; Denburg, S.; Carbotte, R.; Denburg, J.A. Spatial learning during the course of autoimmune disease in MRL mice. Behav. Brain Res. 1993, 54, 57-66. [CrossRef]

79. Vogelweid, C.M.; Wright, D.C.; Johnson, J.C.; Hewett, J.E.; Walker, S.E. Evaluation of memory, learning ability, and clinical neurologic function in pathogen-free mice with systemic lupus erythematosus. Arthritis Rheum. 1994, 37, 889-897. [CrossRef] [PubMed]

80. Subramaniyan, S.; Heo, S.; Patil, S.; Li, L.; Hoger, H.; Pollak, A.; Lubec, G. A hippocampal nicotinic acetylcholine alpha 7-containing receptor complex is linked to memory retrieval in the multiple-T-maze in C57BL/6j mice. Behav. Brain Res. 2014, 270, 137-145. [CrossRef] [PubMed]

81. Ghafari, M.; Falsafi, S.K.; Hoeger, H.; Lubec, G. Hippocampal levels of GluR1 and GluR2 complexes are modulated by training in the multiple T-Maze in C57BL/6J mice. Brain Struct. Funct. 2012, 217, 353-362. [CrossRef] [PubMed]

82. Pioli, E.Y.; Gaskill, B.N.; Gilmour, G.; Tricklebank, M.D.; Dix, S.L.; Bannerman, D.; Garner, J.P. An automated maze task for assessing hippocampus-sensitive memory in mice. Behav. Brain Res. 2014, 261, $249-257$. [CrossRef] [PubMed]

83. Lalonde, R. The neurobiological basis of spontaneous alternation. Neurosci. Biobehav. Rev. 2002, 26, 91-104. [CrossRef]

84. Jeltsch-David, H.; Muller, S. Autoimmunity, neuroinflammation, pathogen load: A decisive crosstalk in neuropsychiatric SLE. J. Autoimmun. 2016, 74, 13-26. [CrossRef] [PubMed]

85. Muller, S.; Brun, S.; René, F.; de Sèze, J.; Loeffler, J.P.; Jeltsch-David, H. Autophagy in neuroinflammatory diseases. Autoimmun. Rev. 2017, 16, 856-874. [CrossRef] [PubMed]

86. Cunningham, C.L.; Shields, C.N. Effects of sex on ethanol conditioned place preference, activity and variability in C57BL/6J and DBA/2J mice. Pharmacol. Biochem. Behav. 2018, 173, 84-89. [CrossRef] [PubMed]

87. Katzav, A.; Solodeev, I.; Brodsky, O.; Chapman, J.; Pick, C.G.; Blank, M.; Zhang, W.; Reichlin, M.; Shoenfeld, Y. Induction of autoimmune depression in mice by anti-ribosomal $\mathrm{P}$ antibodies via the limbic system. Arthritis Rheum. 2007, 56, 938-948. [CrossRef] [PubMed]

88. Kowal, C.; DeGiorgio, L.A.; Nakaoka, T.; Hetherington, H.; Huerta, P.T.; Diamond, B.; Volpe, B.T. Cognition and immunity: Antibody impairs memory. Immunity 2004, 21, 179-188. [CrossRef] [PubMed]

89. Huerta, P.T.; Kowal, C.; DeGiorgio, L.A.; Volpe, B.T.; Diamond, B. Immunity and behavior: Antibodies alter emotion. Proc. Natl. Acad. Sci. USA 2006, 103, 678-683. [CrossRef] [PubMed]

90. Yoshio, T.; Okamoto, H.; Hirohata, S.; Minota, S. IgG anti-NR2 glutamate receptor autoantibodies from patients with systemic lupus erythematosus activate endothelial cells. Arthritis Rheum. 2013, 65, 457-463. [CrossRef] [PubMed]

91. Mahajan, S.D.; Parikh, N.U.; Woodruff, T.M.; Jarvis, J.N.; Lopez, M.; Hennon, T.; Cunningham, P.; Quigg, R.J.; Schwartz, S.A.; Alexander, J.J. C5a alters blood-brain barrier integrity in a human in vitro model of systemic lupus erythematosus. Immunology 2015, 146, 130-143. [CrossRef] [PubMed] 
92. Ainiala, H.; Dastidar, P.; Loukkola, J.; Lehtimäki, T.; Korpela, M.; Peltola, J.; Hietaharju, A. Cerebral MRI abnormalities and their association with neuropsychiatric manifestations in SLE: A population-based study. Scand. J. Rheumatol. 2005, 34, 376-382. [CrossRef] [PubMed]

93. Fitzgibbon, B.M.; Fairhall, S.L.; Kirk, I.J.; Kalev-Zylinska, M.; Pui, K.; Dalbeth, N.; Keelan, S.; Robinson, E.; During, M.; McQueen, F.M. Functional MRI in NPSLE patients reveals increased parietal and frontal brain activation during a working memory task compared with controls. Rheumatology 2008, 47, 50-53. [CrossRef] [PubMed]

94. Sibbitt, W.L., Jr.; Brooks, W.M.; Kornfeld, M.; Hart, B.L.; Bankhurst, A.D.; Roldan, C.A. Magnetic resonance imaging and brain histopathology in neuropsychiatric systemic lupus erythematosus. Semin. Arthritis Rheum. 2010, 40, 32-52. [CrossRef] [PubMed]

95. Sarbu, N.; Alobeidi, F.; Toledano, P.; Espinosa, G.; Giles, I.; Rahman, A.; Yousry, T.; Capurro, S.; Jäger, R.; Cervera, R.; Bargalló, N. Brain abnormalities in newly diagnosed neuropsychiatric lupus: Systematic MRI approach and correlation with clinical and laboratory data in a large multicenter cohort. Autoimmun. Rev. 2015, 14, 153-159. [CrossRef] [PubMed]

96. Sarbu, N.; Toledano, P.; Calvo, A.; Roura, E.; Sarbu, M.I.; Espinosa, G.; Lladó, X.; Cervera, R.; Bargalló, N. Advanced MRI techniques: Biomarkers in neuropsychiatric lupus. Lupus 2017, 26, 510-516. [CrossRef] [PubMed]

97. Toledano, P.; Sarbu, N.; Espinosa, G.; Bargalló, N.; Cervera, R. Neuropsychiatric systemic lupus erythematosus: Magnetic resonance imaging findings and correlation with clinical and immunological features. Autoimmun. Rev. 2013, 12, 1166-1170. [CrossRef] [PubMed]

98. Appenzeller, S.; Pike, G.B.; Clarke, A.E. Magnetic resonance imaging in the evaluation of central nervous system manifestations in systemic lupus erythematosus. Clin. Rev. Allergy Immunol. 2008, 34, 361-366. [CrossRef] [PubMed]

99. Appenzeller, S.; Bonilha, L.; Rio, P.A.; Min Li, L.; Costallat, L.T.L.; Cendes, F. Longitudinal analysis of gray and white matter loss in patients with systemic lupus erythematosus. NeuroImage 2007, 34, 694-701. [CrossRef] [PubMed]

100. Postal, M.; Lapa, A.T.; Reis, F.; Rittner, L.; Appenzeller, S. Magnetic resonance imaging in neuropsychiatric systemic lupus erythematosus: Current state of the art and novel approaches. Lupus 2017, 26, 517-521. [CrossRef] [PubMed]

101. Zimmermann, N.; Corrêa, D.G.; Kubo, T.A.; Netto, T.M.; Pereira, D.B.; Fonseca, R.P.; Gasparetto, E.L. Global Cognitive Impairment in Systemic Lupus Erythematosus Patients: A Structural MRI Study. Clin. Neuroradiol. 2017, 27, 23-29. [CrossRef] [PubMed]

102. Luyendijk, J.; Steens, S.C.A.; Ouwendijk, W.J.N.; Steup-Beekman, G.M.; Bollen, E.L.E.M.; van der Grond, J.; Huizinga, T.W.J.; Emmer, B.J.; van Buchem, M.A. Neuropsychiatric systemic lupus erythematosus: Lessons learned from magnetic resonance imaging. Arthritis Rheum. 2011, 63, 722-732. [CrossRef] [PubMed]

103. Mak, A.; Ren, T.; Fu, E.H.; Cheak, A.A.; Ho, R.C. A prospective functional MRI study for executive function in patients with systemic lupus erythematosus without neuropsychiatric symptoms. Semin. Arthritis Rheum. 2012, 41, 849-858. [CrossRef] [PubMed]

104. Sachdev, P.; Chen, X.; Wen, W. White matter hyperintensities in mid-adult life. Curr. Opin. Psychiatry 2008, 21, 268-274. [CrossRef] [PubMed]

105. Jeong, H.W.; Her, M.; Bae, J.S.; Kim, S.-K.; Lee, S.W.; Kim, H.K.; Kim, D.; Park, N.; Chung, W.T.; Lee, S.Y.; et al. Brain MRI in neuropsychiatric lupus: Associations with the 1999 ACR case definitions. Rheumatol. Int. 2015, 35, 861-869. [CrossRef] [PubMed]

106. Ercan, E.; Ingo, C.; Tritanon, O.; Magro-Checa, C.; Smith, A.; Smith, S.; Huizinga, T.; van Buchem, M.A.; Ronen, I. A multimodal MRI approach to identify and characterize microstructural brain changes in neuropsychiatric systemic lupus erythematosus. NeuroImage Clin. 2015, 8, 337-344. [CrossRef] [PubMed]

107. Abda, E.A.; Selim, Z.I.; Radwan, M.E.M.; Mahmoud, N.M.; Herdan, O.M.; Mohamad, K.A.; Hamed, S.A. Markers of acute neuropsychiatric systemic lupus erythematosus: A multidisciplinary evaluation. Rheumatol. Int. 2013, 33, 1243-1253. [CrossRef] [PubMed]

108. Zimny, A.; Szmyrka-Kaczmarek, M.; Szewczyk, P.; Bladowska, J.; Pokryszko-Dragan, A.; Gruszka, E.; Wiland, P.; Sasiadek, M. In vivo evaluation of brain damage in the course of systemic lupus erythematosus using magnetic resonance spectroscopy, perfusion-weighted and diffusion-tensor imaging. Lupus 2014, 23, 10-19. [CrossRef] [PubMed] 
109. Nystedt, J.; Nilsson, M.; Jönsen, A.; Nilsson, P.; Bengtsson, A.; Lilja, Å.; Lätt, J.; Mannfolk, P.; Sundgren, P.C. Altered white matter microstructure in lupus patients: A diffusion tensor imaging study. Arthritis Res. Ther. 2018, 20, 21. [CrossRef] [PubMed]

110. Costallat, B.L.; Ferreira, D.M.; Lapa, A.T.; Rittner, L.; Costallat, L.T.L.; Appenzeller, S. Brain diffusion tensor MRI in systematic lupus erythematosus: A systematic review. Autoimmun. Rev. 2018, 17, 36-43. [CrossRef] [PubMed]

111. Sled, J.G.; Spring, S.; van Eede, M.; Lerch, J.P.; Ullal, S.; Sakić, B. Time course and nature of brain atrophy in the MRL mouse model of central nervous system lupus. Arthritis Rheum. 2009, 60, 1764-1774. [CrossRef] [PubMed]

112. Holmes, H.E.; Powell, N.M.; Ma, D.; Ismail, O.; Harrison, I.F.; Wells, J.A.; Colgan, N.; O'Callaghan, J.M.; Johnson, R.A.; Murray, T.K.; et al. Comparison of in vivo and ex vivo MRI for the detection of structural abnormalities in a mouse model of tauopathy. Front. Neuroinformatics 2017, 11, 20. [CrossRef] [PubMed]

113. McKinney, A.M. Enlargement or asymmetry of the lateral ventricles simulating hydrocephalus. In Atlas of Normal Imaging Variations of the Brain, Skull, and Craniocervical Vasculature; Springer International Publishing: Cham, Switzerland, 2017; pp. 349-369. ISBN 978-3-319-39789-4.

114. Wachinger, C.; Salat, D.H.; Weiner, M.; Reuter, M.; Alzheimer's Disease Neuroimaging Initiative. Whole-brain analysis reveals increased neuroanatomical asymmetries in dementia for hippocampus and amygdala. Brain J. Neurol. 2016, 139, 3253-3266. [CrossRef] [PubMed]

115. Malheiros, J.M.; Paiva, F.F.; Longo, B.M.; Hamani, C.; Covolan, L. Manganese-Enhanced MRI: Biological Applications in Neuroscience. Front. Neurol. 2015, 6, 161. [CrossRef] [PubMed]

116. Kivity, S.; Tsarfaty, G.; Agmon-Levin, N.; Blank, M.; Manor, D.; Konen, E.; Chapman, J.; Reichlin, M.; Wasson, C.; Shoenfeld, Y.; et al. Abnormal olfactory function demonstrated by manganese-enhanced MRI in mice with experimental neuropsychiatric lupus. Ann. N. Y. Acad. Sci. 2010, 1193, 70-77. [CrossRef] [PubMed]

117. Van der Graaf, M. In vivo magnetic resonance spectroscopy: Basic methodology and clinical applications. Eur. Biophys. J. 2010, 39, 527-540. [CrossRef] [PubMed]

118. Lapteva, L.; Nowak, M.; Yarboro, C.H.; Takada, K.; Roebuck-Spencer, T.; Weickert, T.; Bleiberg, J.; Rosenstein, D.; Pao, M.; Patronas, N.; et al. Anti-N-methyl-D-aspartate receptor antibodies, cognitive dysfunction, and depression in systemic lupus erythematosus. Arthritis Rheum. 2006, 54, 2505-2514. [CrossRef] [PubMed]

119. Diamond, B. Antibodies and the brain: Lessons from lupus. J. Immunol. 2010, 185, 2637-2640. [CrossRef] [PubMed]

120. Kowal, C.; DeGiorgio, L.A.; Lee, J.Y.; Edgar, M.A.; Huerta, P.T.; Volpe, B.T.; Diamond, B. Human lupus autoantibodies against NMDA receptors mediate cognitive impairment. Proc. Natl. Acad. Sci. USA 2006, 103, 19854-19859. [CrossRef] [PubMed]

121. Maric, D.; Millward, J.M.; Ballok, D.A.; Szechtman, H.; Denburg, J.A.; Barker, J.L.; Sakić, B. Neurotoxic properties of cerebrospinal fluid from behaviorally impaired autoimmune mice. Brain Res. 2001, 920, 183-193. [CrossRef]

122. Gharavi, A.E.; Mellors, R.C.; Elkon, K.B. IgG anti-cardiolipin antibodies in murine lupus. Clin. Exp. Immunol. 1989, 78, 233-238. [PubMed]

123. Blatt, N.B.; Glick, G.D. Anti-DNA autoantibodies and systemic lupus erythematosus. Pharmacol. Ther. 1999, 83, 125-139. [CrossRef]

124. Amoura, Z.; Chabre, H.; Koutouzov, S.; Lotton, C.; Cabrespines, A.; Bach, J.F.; Jacob, L. Nucleosome-restricted antibodies are detected before anti-dsDNA and/or antihistone antibodies in serum of MRL-Mp lpr/lpr and +/+ mice, and are present in kidney eluates of lupus mice with proteinuria. Arthritis Rheum. 1994, 37, 1684-1688. [CrossRef] [PubMed]

125. Elkon, K.B.; Parnassa, A.P.; Foster, C.L. Lupus autoantibodies target ribosomal P proteins. J. Exp. Med. 1985, 162, 459-471. [CrossRef] [PubMed]

126. Bonfa, E.; Parnassa, A.P.; Rhoads, D.D.; Roufa, D.J.; Wool, I.G.; Elkon, K.B. Antiribosomal S10 antibodies in humans and MRL/lpr mice with systemic lupus erythematosus. Arthritis Rheum. 1989, 32, 1252-1261. [CrossRef] [PubMed]

127. Tsai, C.Y.; Wu, T.H.; Huang, S.F.; Sun, K.H.; Hsieh, S.C.; Han, S.H.; Yu, H.S.; Yu, C.L. Abnormal splenic and thymic IL-4 and TNF-alpha expression in MRL-lpr/lpr mice. Scand. J. Immunol. 1995, 41, 157-163. [CrossRef] [PubMed] 
128. Tomita, M.; Holman, B.J.; Santoro, T.J. Aberrant cytokine gene expression in the hippocampus in murine systemic lupus erythematosus. Neurosci. Lett. 2001, 302, 129-132. [CrossRef]

129. McHale, J.F.; Harari, O.A.; Marshall, D.; Haskard, D.O. TNF-alpha and IL-1 sequentially induce endothelial ICAM-1 and VCAM-1 expression in MRL/lpr lupus-prone mice. J. Immunol. 1999, 163, 3993-4000. [PubMed]

130. Tomita, M.; Holman, B.J.; Williams, L.S.; Pang, K.C.; Santoro, T.J. Cerebellar dysfunction is associated with overexpression of proinflammatory cytokine genes in lupus. J. Neurosci. Res. 2001, 64, 26-33. [CrossRef] [PubMed]

131. Huang, F.P.; Stott, D.I. Restoration of an early, progressive defect in responsiveness to T-cell activation in lupus mice by exogenous IL-2. Autoimmunity 1993, 15, 19-29. [CrossRef] [PubMed]

132. Choi, Y.; Simon-Stoos, K.; Puck, J.M. Hypo-active variant of IL-2 and associated decreased T cell activation contribute to impaired apoptosis in autoimmune prone MRL mice. Eur. J. Immunol. 2002, 32, 677-685. [CrossRef]

133. Suzuki, H.; Yasukawa, K.; Saito, T.; Narazaki, M.; Hasegawa, A.; Taga, T.; Kishimoto, T. Serum soluble interleukin-6 receptor in MRL/lpr mice is elevated with age and mediates the interleukin-6 signal. Eur. J. Immunol. 1993, 23, 1078-1082. [CrossRef] [PubMed]

134. Tang, B.; Matsuda, T.; Akira, S.; Nagata, N.; Ikehara, S.; Hirano, T.; Kishimoto, T. Age-associated increase in interleukin 6 in MRL/lpr mice. Int. Immunol. 1991, 3, 273-278. [CrossRef] [PubMed]

135. Cash, H.; Relle, M.; Menke, J.; Brochhausen, C.; Jones, S.A.; Topley, N.; Galle, P.R.; Schwarting, A. Interleukin 6 (IL-6) deficiency delays lupus nephritis in MRL-Faslpr mice: The IL-6 pathway as a new therapeutic target in treatment of autoimmune kidney disease in systemic lupus erythematosus. J. Rheumatol. 2010, 37, 60-70. [CrossRef] [PubMed]

136. Yang, J.; Li, Q.; Yang, X.; Li, M. Interleukin-9 is associated with elevated anti-double-stranded DNA antibodies in lupus-prone mice. Mol. Med. 2015, 21, 364-370. [CrossRef] [PubMed]

137. Yin, Z.; Bahtiyar, G.; Zhang, N.; Liu, L.; Zhu, P.; Robert, M.E.; McNiff, J.; Madaio, M.P.; Craft, J. IL-10 regulates murine lupus. J. Immunol. Baltim. Md 1950 2002, 169, 2148-2155. [CrossRef]

138. Zhang, Y.; Wang, Z.; Xiao, H.; Liu, X.; Zhu, G.; Yu, D.; Han, G.; Chen, G.; Hou, C.; Ma, N.; et al. Foxd3 suppresses interleukin-10 expression in B cells. Immunology 2017, 150, 478-488. [CrossRef] [PubMed]

139. Huang, F.P.; Feng, G.J.; Lindop, G.; Stott, D.I.; Liew, F.Y. The role of interleukin 12 and nitric oxide in the development of spontaneous autoimmune disease in MRL/MP-lpr/lpr mice. J. Exp. Med. 1996, 183, 1447-1459. [CrossRef] [PubMed]

140. Qiu, F.; Li, T.; Zhang, K.; Wan, J.; Qi, X. CD4(+)B220(+)TCR $\gamma \delta(+) ~ T$ cells produce IL-17 in lupus-prone $\mathrm{MRL/lpr} \mathrm{mice.} \mathrm{Int.} \mathrm{Immunopharmacol.} \mathrm{2016,} \mathrm{38,} \mathrm{31-39.} \mathrm{[CrossRef]} \mathrm{[PubMed]}$

141. Favilli, F.; Anzilotti, C.; Martinelli, L.; Quattroni, P.; De Martino, S.; Pratesi, F.; Neumann, D.; Beermann, S.; Novick, D.; Dinarello, C.A.; et al. IL-18 activity in systemic lupus erythematosus. Ann. N. Y. Acad. Sci. 2009, 1173, 301-309. [CrossRef] [PubMed]

142. Esfandiari, E.; McInnes, I.B.; Lindop, G.; Huang, F.P.; Field, M.; Komai-Koma, M.; Wei, X.; Liew, F.Y. A proinflammatory role of IL-18 in the development of spontaneous autoimmune disease. J. Immunol. 2001, 167, 5338-5347. [CrossRef] [PubMed]

143. Herber, D.; Brown, T.P.; Liang, S.; Young, D.A.; Collins, M.; Dunussi-Joannopoulos, K. IL-21 has a pathogenic role in a lupus-prone mouse model and its blockade with IL-21R.Fc reduces disease progression. J. Immunol. 2007, 178, 3822-3830. [CrossRef] [PubMed]

144. Yang, X.; Weng, Q.; Hu, L.; Yang, L.; Wang, X.; Xiang, X.; Hong, B.; Gong, X.; Wang, Q. Increased interleukin-22 levels in lupus nephritis and its associated with disease severity: A study in both patients and lupus-like mice model. Clin. Exp. Rheumatol. 2018.

145. Yui, M.A.; Brissette, W.H.; Brennan, D.C.; Wuthrich, R.P.; Rubin-Kelley, V.E. Increased macrophage colony-stimulating factor in neonatal and adult autoimmune MRL-lpr mice. Am. J. Pathol. 1991, 139, 255-261. [PubMed]

146. Leng, L.; Chen, L.; Fan, J.; Greven, D.; Arjona, A.; Du, X.; Austin, D.; Kashgarian, M.; Yin, Z.; Huang, X.R.; et al. A small-molecule macrophage migration inhibitory factor antagonist protects against glomerulonephritis in lupus-prone NZB/NZW F1 and MRL/lpr mice. J. Immunol. 2011, 186, 527-538. [CrossRef] [PubMed]

147. Santoro, T.J.; Benjamin, W.R.; Oppenheim, J.J.; Steinberg, A.D. The cellular basis for immune interferon production in autoimmune MRL-Ipr/Ipr mice. J. Immunol. 1983, 131, 265-268. [PubMed] 
148. Tomita, M.; Khan, R.L.; Blehm, B.H.; Santoro, T.J. The potential pathogenetic link between peripheral immune activation and the central innate immune response in neuropsychiatric systemic lupus erythematosus. Med. Hypotheses 2004, 62, 325-335. [CrossRef] [PubMed]

149. Kim, N.; Ussin, L.; Cheng, X.; Murali, R.; Sullivan, K.E. TNFalpha inhibition in MRL/lpr mice ameliorates pulmonary but not renal disease. J. Autoimmun. 2002, 19, 215-222. [CrossRef] [PubMed]

150. Wen, J.; Xia, Y.; Stock, A.; Michaelson, J.S.; Burkly, L.C.; Gulinello, M.; Putterman, C. Neuropsychiatric disease in murine lupus is dependent on the TWEAK/Fn14 pathway. J. Autoimmun. 2013, 43, 44-54. [CrossRef] [PubMed]

151. Dantzer, R. Cytokine, sickness behavior, and depression. Immunol. Allergy Clin. North Am. 2009, 29, $247-264$. [CrossRef] [PubMed]

152. Marshall, D. MRL/lpr lupus-prone mice show exaggerated ICAM-1-dependent leucocyte adhesion and transendothelial migration in response to TNF-. Rheumatology 2003, 42, 929-934. [CrossRef] [PubMed]

153. Ballok, D.A.; Woulfe, J.; Sur, M.; Cyr, M.; Sakić, B. Hippocampal damage in mouse and human forms of systemic autoimmune disease. Hippocampus 2004, 14, 649-661. [CrossRef] [PubMed]

154. Banks, W.A.; Kastin, A.J.; Gutierrez, E.G. Penetration of interleukin-6 across the murine blood-brain barrier. Neurosci. Lett. 1994, 179, 53-56. [CrossRef]

155. Brey, R.L.; Amato, A.A.; Kagan-Hallet, K.; Rhine, C.B.; Stallworth, C.L. Anti-Intercellular Adhesion Molecule-1 (ICAM-1) antibody treatment prevents central and peripheral nervous system disease in autoimmune-prone mice. Lupus 1997, 6, 645-651. [CrossRef] [PubMed]

156. Bernhagen, J.; Calandra, T.; Mitchell, R.A.; Martin, S.B.; Tracey, K.J.; Voelter, W.; Manogue, K.R.; Cerami, A.; Bucala, R. MIF is a pituitary-derived cytokine that potentiates lethal endotoxaemia. Nature 1993, 365, 756-759. [CrossRef] [PubMed]

157. Bernhagen, J.; Bacher, M.; Calandra, T.; Metz, C.N.; Doty, S.B.; Donnelly, T.; Bucala, R. An essential role for macrophage migration inhibitory factor in the tuberculin delayed-type hypersensitivity reaction. J. Exp. Med. 1996, 183, 277-282. [CrossRef] [PubMed]

158. Hoi, A.Y.; Morand, E.F.; Leech, M. Is macrophage migration inhibitory factor a therapeutic target in systemic lupus erythematosus? Immunol. Cell Biol. 2003, 81, 367-373. [CrossRef] [PubMed]

159. Nishibori, M.; Nakaya, N.; Tahara, A.; Kawabata, M.; Mori, S.; Saeki, K. Presence of macrophage migration inhibitory factor (MIF) in ependyma, astrocytes and neurons in the bovine brain. Neurosci. Lett. 1996, 213, 193-196. [CrossRef]

160. Bacher, M.; Meinhardt, A.; Lan, H.Y.; Dhabhar, F.S.; Mu, W.; Metz, C.N.; Chesney, J.A.; Gemsa, D.; Donnelly, T.; Atkins, R.C.; et al. MIF expression in the rat brain: Implications for neuronal function. Mol. Med. Camb. Mass 1998, 4, 217-230. [CrossRef] [PubMed]

161. Fagone, P.; Mazzon, E.; Cavalli, E.; Bramanti, A.; Petralia, M.C.; Mangano, K.; Al-Abed, Y.; Bramati, P.; Nicoletti, F. Contribution of the macrophage migration inhibitory factor superfamily of cytokines in the pathogenesis of preclinical and human multiple sclerosis: In silico and in vivo evidences. J. Neuroimmunol. 2018, 322, 46-56. [CrossRef] [PubMed]

162. Nicoletti, F.; Créange, A.; Orlikowski, D.; Bolgert, F.; Mangano, K.; Metz, C.; Di Marco, R.; Al Abed, Y. Macrophage migration inhibitory factor (MIF) seems crucially involved in Guillain-Barré syndrome and experimental allergic neuritis. J. Neuroimmunol. 2005, 168, 168-174. [CrossRef] [PubMed]

163. Benedek, G.; Meza-Romero, R.; Jordan, K.; Zhang, Y.; Nguyen, H.; Kent, G.; Li, J.; Siu, E.; Frazer, J.; Piecychna, M.; et al. MIF and D-DT are potential disease severity modifiers in male MS subjects. Proc. Natl. Acad. Sci. USA 2017, 114, E8421-E8429. [CrossRef] [PubMed]

164. Bay-Richter, C.; Janelidze, S.; Sauro, A.; Bucala, R.; Lipton, J.; Deierborg, T.; Brundin, L. Behavioural and neurobiological consequences of macrophage migration inhibitory factor gene deletion in mice. J. Neuroinflammation 2015, 12, 163. [CrossRef] [PubMed]

165. Bloom, J.; Al-Abed, Y. MIF: Mood improving/inhibiting factor? J. Neuroinflammation 2014, 11, 1-11. [CrossRef] [PubMed]

166. Lang, T.; Foote, A.; Lee, J.P.W.; Morand, E.F.; Harris, J. MIF: Implications in the pathoetiology of systemic lupus erythematosus. Front. Immunol. 2015, 6, 577. [CrossRef] [PubMed] 
167. Hoi, A.Y.; Hickey, M.J.; Hall, P.; Yamana, J.; O’Sullivan, K.M.; Santos, L.L.; James, W.G.; Kitching, A.R.; Morand, E.F. Macrophage migration inhibitory factor deficiency attenuates macrophage recruitment, glomerulonephritis, and lethality in MRL/lpr mice. J. Immunol. Baltim. Md 1950 2006, 177, 5687-5696. [CrossRef]

168. Bucala, R. Role of MIF gene polymorphisms in systemic lupus erythematosus and prospects for therapeutic intervention. Arthritis Res. Ther. 2012, 14, A33. [CrossRef]

169. Feng, X.; Chen, W.; Xiao, L.; Gu, F.; Huang, J.; Tsao, B.P.; Sun, L. Artesunate inhibits type I interferon induced production of macrophage migration inhibitory factor in patients with systemic lupus erythematosus. Lupus 2017, 26, 62-72. [CrossRef] [PubMed]

170. Bae, S.C.; Lee, Y.H. Circulating macrophage migration inhibitory factor levels and its polymorphisms in systemic lupus erythematosus: A meta-analysis. Cell. Mol. Biol. 2017, 63, 74-79. [CrossRef] [PubMed]

171. Lapter, S.; Marom, A.; Meshorer, A.; Elmann, A.; Sharabi, A.; Vadai, E.; Neufeld, A.; Sztainberg, Y.; Gil, S.; Getselter, D.; et al. Amelioration of brain pathology and behavioral dysfunction in mice with lupus following treatment with a tolerogenic peptide. Arthritis Rheum. 2009, 60, 3744-3754. [CrossRef] [PubMed]

172. Lapter, S.; Ben-David, H.; Sharabi, A.; Zinger, H.; Telerman, A.; Gordin, M.; Leng, L.; Bucala, R.; Shachar, I.; Mozes, E. A role for the B-cell CD74/macrophage migration inhibitory factor pathway in the immunomodulation of systemic lupus erythematosus by a therapeutic tolerogenic peptide. Immunology 2011, 132, 87-95. [CrossRef] [PubMed]

173. Louveau, A.; Smirnov, I.; Keyes, T.J.; Eccles, J.D.; Rouhani, S.J.; Peske, J.D.; Derecki, N.C.; Castle, D.; Mandell, J.W.; Lee, K.S.; et al. Structural and functional features of central nervous system lymphatic vessels. Nature 2015, 523, 337-341. [CrossRef] [PubMed]

174. Louveau, A.; Harris, T.H.; Kipnis, J. Revisiting the mechanisms of CNS immune privilege. Trends Immunol. 2015, 36, 569-577. [CrossRef] [PubMed]

175. Engelhardt, B.; Vajkoczy, P.; Weller, R.O. The movers and shapers in immune privilege of the CNS. Nat. Immunol. 2017, 18, 123-131. [CrossRef] [PubMed]

176. Ma, X.; Foster, J.; Sakić, B. Distribution and prevalence of leukocyte phenotypes in brains of lupus-prone mice. J. Neuroimmunol. 2006, 179, 26-36. [CrossRef] [PubMed]

177. Morawski, P.A.; Qi, C.-F.; Bolland, S. Non-pathogenic tissue-resident CD8+ T cells uniquely accumulate in the brains of lupus-prone mice. Sci. Rep. 2017, 7, 40838. [CrossRef] [PubMed]

178. Kim, S.J.; Lee, K.; Diamond, B. Follicular helper T cells in systemic lupus erythematosus. Front. Immunol. 2018, 9, 1793. [CrossRef] [PubMed]

179. O'Sullivan, F.X.; Vogelweid, C.M.; Besch-Williford, C.L.; Walker, S.E. Differential effects of CD4+ T cell depletion on inflammatory central nervous system disease, arthritis and sialadenitis in MRL/lpr mice. J. Autoimmun. 1995, 8, 163-175. [CrossRef] [PubMed]

180. Ulivieri, C.; Baldari, C.T. Regulation of T cell activation and differentiation by extracellular vesicles and their pathogenic role in systemic lupus erythematosus and multiple sclerosis. Molecules 2017, 22, 225. [CrossRef] [PubMed]

181. Wen, J.; Doerner, J.; Weidenheim, K.; Xia, Y.; Stock, A.; Michaelson, J.S.; Baruch, K.; Deczkowska, A.; Gulinello, M.; Schwartz, M.; et al. TNF-like weak inducer of apoptosis promotes blood brain barrier disruption and increases neuronal cell death in MRL/lpr mice. J. Autoimmun. 2015, 60, 40-50. [CrossRef] [PubMed]

182. Bódi, N.; Polgár, A.; Kiss, E.; Mester, Á.; Poór, G.; Kéri, S. Reduced volumes of the CA1 and CA4-dentate gyrus hippocampal subfields in systemic lupus erythematosus. Lupus 2017, 26, 1378-1382. [CrossRef] [PubMed]

183. Barcellini, W.; Rizzardi, G.P.; Borghi, M.O.; Nicoletti, F.; Fain, C.; Del Papa, N.; Meroni, P.L. In vitro type-1 and type-2 cytokine production in systemic lupus erythematosus: Lack of relationship with clinical disease activity. Lupus 1996, 5, 139-145. [CrossRef] [PubMed]

184. Kempermann, G.; Song, H.; Gage, F.H. Neurogenesis in the adult hippocampus. Cold Spring Harb. Perspect. Biol. 2015, 7, a018812. [CrossRef] [PubMed]

185. Hayashi, Y.; Jinnou, H.; Sawamoto, K.; Hitoshi, S. Adult neurogenesis and its role in brain injury and psychiatric diseases. J. Neurochem. 2018. [CrossRef] [PubMed]

186. Sheffield, M.E.; Dombeck, D.A. Dendritic mechanisms of hippocampal place field formation. Curr. Opin. Neurobiol. 2018, 54, 1-11. [CrossRef] [PubMed] 
187. Stanojcic, M.; Burstyn-Cohen, T.; Nashi, N.; Lemke, G.; Sakić, B. Disturbed distribution of proliferative brain cells during lupus-like disease. Brain. Behav. Immun. 2009, 23, 1003-1013. [CrossRef] [PubMed]

188. Sakić, B.; Kirkham, D.L.; Ballok, D.A.; Mwanjewe, J.; Fearon, I.M.; Macri, J.; Yu, G.; Sidor, M.M.; Denburg, J.A.; Szechtman, H.; et al. Proliferating brain cells are a target of neurotoxic CSF in systemic autoimmune disease. J. Neuroimmunol. 2005, 169, 68-85. [CrossRef] [PubMed]

189. Tashiro, A.; Sandler, V.M.; Toni, N.; Zhao, C.; Gage, F.H. NMDA-receptor-mediated, cell-specific integration of new neurons in adult dentate gyrus. Nature 2006, 442, 929-933. [CrossRef] [PubMed]

190. Faust, T.W.; Chang, E.H.; Kowal, C.; Berlin, R.; Gazaryan, I.G.; Bertini, E.; Zhang, J.; Sanchez-Guerrero, J.; Fragoso-Loyo, H.E.; Volpe, B.T.; et al. Neurotoxic lupus autoantibodies alter brain function through two distinct mechanisms. Proc. Natl. Acad. Sci. USA 2010, 107, 18569-18574. [CrossRef] [PubMed]

191. Alawieh, A.; Elvington, A.; Tomlinson, S. Complement in the homeostatic and ischemic brain. Front. Immunol. 2015, 6, 417. [CrossRef] [PubMed]

192. Presumey, J.; Bialas, A.R.; Carroll, M.C. Complement system in neural synapse elimination in development and disease. Adv. Immunol. 2017, 135, 53-79. [CrossRef] [PubMed]

193. Alexander, J.J.; Jacob, A.; Bao, L.; Macdonald, R.L.; Quigg, R.J. Complement-dependent apoptosis and inflammatory gene changes in murine lupus cerebritis. J. Immunol. 2005, 175, 8312-8319. [CrossRef] [PubMed]

194. Hong, S.; Dissing-Olesen, L.; Stevens, B. New insights on the role of microglia in synaptic pruning in health and disease. Curr. Opin. Neurobiol. 2016, 36, 128-134. [CrossRef] [PubMed]

195. Song, J.; Olsen, R.H.J.; Sun, J.; Ming, G.-L.; Song, H. Neuronal circuitry mechanisms regulating adult mammalian neurogenesis. Cold Spring Harb. Perspect. Biol. 2016, 8, a018937. [CrossRef] [PubMed]

196. Lieberman, O.J.; McGuirt, A.F.; Tang, G.; Sulzer, D. Roles for neuronal and glial autophagy in synaptic pruning during development. Neurobiol. Dis. 2018. [CrossRef] [PubMed]

197. Alexander, J.J.; Bao, L.; Jacob, A.; Kraus, D.M.; Holers, V.M.; Quigg, R.J. Administration of the soluble complement inhibitor, Crry-Ig, reduces inflammation and aquaporin 4 expression in lupus cerebritis. Biochim. Biophys. Acta 2003, 1639, 169-176. [CrossRef] [PubMed]

198. Telerman, A.; Lapter, S.; Sharabi, A.; Zinger, H.; Mozes, E. Induction of hippocampal neurogenesis by a tolerogenic peptide that ameliorates lupus manifestations. J. Neuroimmunol. 2011, 232, 151-157. [CrossRef] [PubMed]

199. Lee, J.Y.; Huerta, P.T.; Zhang, J.; Kowal, C.; Bertini, E.; Volpe, B.T.; Diamond, B. Neurotoxic autoantibodies mediate congenital cortical impairment of offspring in maternal lupus. Nat. Med. 2009, 15, 91-96. [CrossRef] [PubMed]

200. Loheswaran, G.; Kapadia, M.; Gladman, M.; Pulapaka, S.; Xu, L.; Stanojcic, M.; Sakić, B. Altered neuroendocrine status at the onset of CNS lupus-like disease. Brain. Behav. Immun. 2013, 32, 86-93. [CrossRef] [PubMed]

201. Ballok, D.A.; Millward, J.M.; Sakić, B. Neurodegeneration in autoimmune MRL-lpr mice as revealed by Fluoro Jade B staining. Brain Res. 2003, 964, 200-210. [CrossRef]

202. Silverman, M.N.; Pearce, B.D.; Biron, C.A.; Miller, A.H. Immune modulation of the hypothalamic-pituitary-adrenal (HPA) axis during viral infection. Viral Immunol. 2005, 18, 41-78. [CrossRef] [PubMed]

203. Sakić, B.; Maric, I.; Koeberle, P.D.; Millward, J.M.; Szechtman, H.; Maric, D.; Denburg, J.A. Increased TUNEL staining in brains of autoimmune Fas-deficient mice. J. Neuroimmunol. 2000, 104, 147-154. [CrossRef]

204. Sakić, B.; Szechtman, H.; Denburg, J.A.; Gorny, G.; Kolb, B.; Whishaw, I.Q. Progressive atrophy of pyramidal neuron dendrites in autoimmune MRL-lpr mice. J. Neuroimmunol. 1998, 87, 162-170. [CrossRef]

205. Verma, M.; Callio, J.; Otero, P.A.; Sekler, I.; Wills, Z.P.; Chu, C.T. Mitochondrial calcium dysregulation contributes to dendrite degeneration mediated by PD/LBD-associated LRRK2 mutants. J. Neurosci. 2017, 37, 11151-11165. [CrossRef] [PubMed]

206. Verma, M.; Wills, Z.; Chu, C.T. Excitatory dendritic mitochondrial calcium toxicity: Implications for Parkinson's and other neurodegenerative diseases. Front. Neurosci. 2018, 12, 523. [CrossRef] [PubMed]

207. Arcuri, C.; Mecca, C.; Bianchi, R.; Giambanco, I.; Donato, R. The pathophysiological role of microglia in dynamic surveillance, phagocytosis and structural remodeling of the developing CNS. Front. Mol. Neurosci. 2017, 10, 191. [CrossRef] [PubMed] 
208. Alexander, J.J.; Jacob, A.; Vezina, P.; Sekine, H.; Gilkeson, G.S.; Quigg, R.J. Absence of functional alternative complement pathway alleviates lupus cerebritis. Eur. J. Immunol. 2007, 37, 1691-1701. [CrossRef] [PubMed]

209. Jacob, A.; Hack, B.; Chiang, E.; Garcia, J.G.N.; Quigg, R.J.; Alexander, J.J. C5a alters blood-brain barrier integrity in experimental lupus. FASEB J. 2010, 24, 1682-1688. [CrossRef] [PubMed]

210. Vogelweid, C.M.; Johnson, G.C.; Besch-Williford, C.L.; Basler, J.; Walker, S.E. Inflammatory central nervous system disease in lupus-prone MRL/lpr mice: Comparative histologic and immunohistochemical findings. J. Neuroimmunol. 1991, 35, 89-99. [CrossRef]

211. Mahajan, S.D.; Tutino, V.M.; Redae, Y.; Meng, H.; Siddiqui, A.; Woodruff, T.M.; Jarvis, J.N.; Hennon, T.; Schwartz, S.; Quigg, R.J.; et al. C5a induces caspase-dependent apoptosis in brain vascular endothelial cells in experimental lupus. Immunology 2016, 148, 407-419. [CrossRef] [PubMed]

212. Wen, J.; Chen, C.H.; Stock, A.; Doerner, J.; Gulinello, M.; Putterman, C. Intracerebroventricular administration of TNF-like weak inducer of apoptosis induces depression-like behavior and cognitive dysfunction in non-autoimmune mice. Brain. Behav. Immun. 2016, 54, 27-37. [CrossRef] [PubMed]

213. Schmitt, N. Role of T follicular helper cells in multiple sclerosis. J. Nat. Sci. 2015, 1, e139. [PubMed]

214. Stern, J.N.H.; Yaari, G.; Vander Heiden, J.A.; Church, G.; Donahue, W.F.; Hintzen, R.Q.; Huttner, A.J.; Laman, J.D.; Nagra, R.M.; Nylander, A.; et al. B cells populating the multiple sclerosis brain mature in the draining cervical lymph nodes. Sci. Transl. Med. 2014, 6, 248ra107. [CrossRef] [PubMed]

215. Stock, A.D.; Wen, J.; Doerner, J.; Herlitz, L.C.; Gulinello, M.; Putterman, C. Neuropsychiatric systemic lupus erythematosus persists despite attenuation of systemic disease in MRL/lpr mice. J. Neuroinflammation 2015, 12, 205. [CrossRef] [PubMed]

216. Wen, J.; Doerner, J.; Chalmers, S.; Stock, A.; Wang, H.; Gullinello, M.; Shlomchik, M.J.; Putterman, C. B cell and/or autoantibody deficiency do not prevent neuropsychiatric disease in murine systemic lupus erythematosus. J. Neuroinflammation 2016, 13, 73. [CrossRef] [PubMed]

217. Marmont du Haut Champ, A.M. Hematopoietic stem cell transplantation for systemic lupus erythematosus. Clin. Dev. Immunol. 2012, 2012, 380391. [CrossRef] [PubMed]

218. Leone, A.; Radin, M.; Almarzooqi, A.M.; Al-Saleh, J.; Roccatello, D.; Sciascia, S.; Khamashta, M. Autologous hematopoietic stem cell transplantation in systemic lupus erythematosus and antiphospholipid syndrome: A systematic review. Autoimmun. Rev. 2017, 16, 469-477. [CrossRef] [PubMed]

219. Lisukov, I.A.; Sizikova, S.A.; Kulagin, A.D.; Kruchkova, I.V.; Gilevich, A.V.; Konenkova, L.P.; Zonova, E.V.; Chernykh, E.R.; Leplina, O.Y.; Sentyakova, T.N.; et al. High-dose immunosuppression with autologous stem cell transplantation in severe refractory systemic lupus erythematosus. Lupus 2004, 13, 89-94. [CrossRef] [PubMed]

220. Lehnhardt, F.G.; Scheid, C.; Holtik, U.; Burghaus, L.; Neveling, M.; Impekoven, P.; Rüger, A.; Hallek, M.; Jacobs, A.H.; Rubbert, A. Autologous blood stem cell transplantation in refractory systemic lupus erythematodes with recurrent longitudinal myelitis and cerebral infarction. Lupus 2006, 15, 240-243. [CrossRef] [PubMed]

221. Sakata, K.; Nakayamada, S.; Miyazaki, Y.; Kubo, S.; Ishii, A.; Nakano, K.; Tanaka, Y. Up-regulation of TLR7-mediated IFN- $\alpha$ production by plasmacytoid dendritic cells in patients with systemic lupus erythematosus. Front. Immunol. 2018, 9, 1957. [CrossRef] [PubMed]

222. Pérez de Lema, G.; Maier, H.; Nieto, E.; Vielhauer, V.; Luckow, B.; Mampaso, F.; Schlöndorff, D. Chemokine expression precedes inflammatory cell infiltration and chemokine receptor and cytokine expression during the initiation of murine lupus nephritis. J. Am. Soc. Nephrol. 2001, 12, 1369-1382. [PubMed]

223. Sakić, B.; Kolb, B.; Whishaw, I.Q.; Gorny, G.; Szechtman, H.; Denburg, J.A. Immunosuppression prevents neuronal atrophy in lupus-prone mice: Evidence for brain damage induced by autoimmune disease? J. Neuroimmunol. 2000, 111, 93-101. [CrossRef]

224. Chalmers, S.A.; Wen, J.; Doerner, J.; Stock, A.; Cuda, C.M.; Makinde, H.M.; Perlman, H.; Bosanac, T.; Webb, D.; Nabozny, G.; et al. Highly selective inhibition of Bruton's tyrosine kinase attenuates skin and brain disease in murine lupus. Arthritis Res. Ther. 2018, 20, 10. [CrossRef] [PubMed]

225. Magro-Checa, C.; Zirkzee, E.J.; Huizinga, T.W.; Steup-Beekman, G.M. Management of Neuropsychiatric Systemic Lupus Erythematosus: Current Approaches and Future Perspectives. Drugs 2016, 76, 459-483. [CrossRef] [PubMed] 
226. Bertsias, G.K.; Ioannidis, J.P.A.; Aringer, M.; Bollen, E.; Bombardieri, S.; Bruce, I.N.; Cervera, R.; Dalakas, M.; Doria, A.; Hanly, J.G.; et al. EULAR recommendations for the management of systemic lupus erythematosus with neuropsychiatric manifestations: Report of a task force of the EULAR standing committee for clinical affairs. Ann. Rheum. Dis. 2010, 69, 2074-2082. [CrossRef] [PubMed]

227. Fanouriakis, A.; Boumpas, D.T.; Bertsias, G.K. Pathogenesis and treatment of CNS lupus. Curr. Opin. Rheumatol. 2013, 25, 577-583. [CrossRef] [PubMed]

228. Pamfil, C.; Fanouriakis, A.; Damian, L.; Rinzis, M.; Sidiropoulos, P.; Tsivgoulis, G.; Rednic, S.; Bertsias, G.; Boumpas, D.T. EULAR recommendations for neuropsychiatric systemic lupus erythematosus vs. usual care: Results from two European centres. Rheumatology 2015, 54, 1270-1278. [CrossRef] [PubMed]

229. Chalmers, S.A.; Wen, J.; Shum, J.; Doerner, J.; Herlitz, L.; Putterman, C. CSF-1R inhibition attenuates renal and neuropsychiatric disease in murine lupus. Clin. Immunol. 2017, 185, 100-108. [CrossRef] [PubMed]

230. Shi, D.; Tian, T.; Yao, S.; Cao, K.; Zhu, X.; Zhang, M.; Wen, S.; Li, L.; Shi, M.; Zhou, H. FTY720 attenuates behavioral deficits in a murine model of systemic lupus erythematosus. Brain. Behav. Immun. 2018, 70, 293-304. [CrossRef] [PubMed]

231. Mike, E.V.; Makinde, H.M.; Der, E.; Stock, A.; Gulinello, M.; Gadhvi, G.T.; Winter, D.R.; Cuda, C.M.; Putterman, C. Neuropsychiatric systemic lupus erythematosus is dependent on sphingosine-1-phosphate signaling. Front. Immunol. 2018, 9, 2189. [CrossRef] [PubMed]

232. Ravanan, P.; Srikumar, I.F.; Talwar, P. Autophagy: The spotlight for cellular stress responses. Life Sci. 2017, 188, 53-67. [CrossRef] [PubMed]

233. Anding, A.L.; Baehrecke, E.H. Cleaning house: Selective autophagy of organelles. Dev. Cell 2017, 41, 10-22. [CrossRef] [PubMed]

234. Mizushima, N.; Komatsu, M. Autophagy: Renovation of cells and tissues. Cell 2011, 147, 728-741. [CrossRef] [PubMed]

235. Kaushik, S.; Cuervo, A.M. The coming of age of chaperone-mediated autophagy. Nat. Rev. Mol. Cell Biol. 2018, 19, 365-381. [CrossRef] [PubMed]

236. Mijaljica, D.; Prescott, M.; Devenish, R.J. Microautophagy in mammalian cells: Revisiting a 40-year-old conundrum. Autophagy 2011, 7, 673-682. [CrossRef] [PubMed]

237. Cuervo, A.M.; Wong, E. Chaperone-mediated autophagy: Roles in disease and aging. Cell Res. 2014, 24, 92-104. [CrossRef] [PubMed]

238. Zhong, Z.; Sanchez-Lopez, E.; Karin, M. Autophagy, NLRP3 inflammasome and auto-inflammatory/immune diseases. Clin. Exp. Rheumatol. 2016, 34, 12-16. [PubMed]

239. Qian, M.; Fang, X.; Wang, X. Autophagy and inflammation. Clin. Transl. Med. 2017, 6, 24. [CrossRef] [PubMed]

240. Ge, Y.; Huang, M.; Yao, Y. Autophagy and proinflammatory cytokines: Interactions and clinical implications. Cytokine Growth Factor Rev. 2018, 43, 38-46. [CrossRef] [PubMed]

241. Martinez, J.; Cunha, L.D.; Park, S.; Yang, M.; Lu, Q.; Orchard, R.; Li, Q.-Z.; Yan, M.; Janke, L.; Guy, C.; et al. Noncanonical autophagy inhibits the autoinflammatory, lupus-like response to dying cells. Nature 2016, 533, 115-119. [CrossRef] [PubMed]

242. Alirezaei, M.; Fox, H.S.; Flynn, C.T.; Moore, C.S.; Hebb, A.L.O.; Frausto, R.F.; Bhan, V.; Kiosses, W.B.; Whitton, J.L.; Robertson, G.S.; et al. Elevated ATG5 expression in autoimmune demyelination and multiple sclerosis. Autophagy 2009, 5, 152-158. [CrossRef] [PubMed]

243. Bhattacharya, A.; Parillon, X.; Zeng, S.; Han, S.; Eissa, N.T. Deficiency of autophagy in dendritic cells protects against experimental autoimmune encephalomyelitis. J. Biol. Chem. 2014, 289, 26525-26532. [CrossRef] [PubMed]

244. Liang, P.; Le, W. Role of autophagy in the pathogenesis of multiple sclerosis. Neurosci. Bull. 2015, 31, 435-444. [CrossRef] [PubMed]

245. Patergnani, S.; Castellazzi, M.; Bonora, M.; Marchi, S.; Casetta, I.; Pugliatti, M.; Giorgi, C.; Granieri, E.; Pinton, P. Autophagy and mitophagy elements are increased in body fluids of multiple sclerosis-affected individuals. J. Neurol. Neurosurg. Psychiatry 2018, 89, 439-441. [CrossRef] [PubMed]

246. Nicoletti, F.; Fagone, P.; Meroni, P.; McCubrey, J.; Bendtzen, K. mTOR as a multifunctional therapeutic target in HIV infection. Drug Discov. Today 2011, 16, 715-721. [CrossRef] [PubMed] 
247. Donia, M.; Mangano, K.; Amoroso, A.; Mazzarino, M.C.; Imbesi, R.; Castrogiovanni, P.; Coco, M.; Meroni, P.; Nicoletti, F. Treatment with rapamycin ameliorates clinical and histological signs of protracted relapsing experimental allergic encephalomyelitis in Dark Agouti rats and induces expansion of peripheral CD4+CD25+Foxp3+ regulatory T cells. J. Autoimmun. 2009, 33, 135-140. [CrossRef] [PubMed]

248. Mammana, S.; Bramanti, P.; Mazzon, E.; Cavalli, E.; Basile, M.S.; Fagone, P.; Petralia, M.C.; McCubrey, J.A.; Nicoletti, F.; Mangano, K. Preclinical evaluation of the PI3K/Akt/mTOR pathway in animal models of multiple sclerosis. Oncotarget 2018, 9, 8263-8277. [CrossRef] [PubMed]

249. Warner, L.M.; Adams, L.M.; Sehgal, S.N. Rapamycin prolongs survival and arrests pathophysiologic changes in murine systemic lupus erythematosus. Arthritis Rheum. 1994, 37, 289-297. [CrossRef] [PubMed]

250. Fernandez, D.; Bonilla, E.; Mirza, N.; Niland, B.; Perl, A. Rapamycin reduces disease activity and normalizes T cell activation-induced calcium fluxing in patients with systemic lupus erythematosus. Arthritis Rheum. 2006, 54, 2983-2988. [CrossRef] [PubMed]

251. Lai, Z.-W.; Kelly, R.; Winans, T.; Marchena, I.; Shadakshari, A.; Yu, J.; Dawood, M.; Garcia, R.; Tily, H.; Francis, L.; et al. Sirolimus in patients with clinically active systemic lupus erythematosus resistant to, or intolerant of, conventional medications: A single-arm, open-label, phase 1/2 trial. Lancet 2018, 391, 1186-1196. [CrossRef]

252. Su, P.; Zhang, J.; Wang, D.; Zhao, F.; Cao, Z.; Aschner, M.; Luo, W. The role of autophagy in modulation of neuroinflammation in microglia. Neuroscience 2016, 319, 155-167. [CrossRef] [PubMed]

253. Tang, G.; Gudsnuk, K.; Kuo, S.-H.; Cotrina, M.L.; Rosoklija, G.; Sosunov, A.; Sonders, M.S.; Kanter, E.; Castagna, C.; Yamamoto, A.; et al. Loss of mTOR-dependent macroautophagy causes autistic-like synaptic pruning deficits. Neuron 2014, 83, 1131-1143. [CrossRef] [PubMed]

254. Kim, H.-J.; Cho, M.-H.; Shim, W.H.; Kim, J.K.; Jeon, E.-Y.; Kim, D.-H.; Yoon, S.-Y. Deficient autophagy in microglia impairs synaptic pruning and causes social behavioral defects. Mol. Psychiatry 2017, 22, 1576-1584. [CrossRef] [PubMed]

255. Heckmann, B.L.; Boada-Romero, E.; Cunha, L.D.; Magne, J.; Green, D.R. LC3-associated phagocytosis and inflammation. J. Mol. Biol. 2017, 429, 3561-3576. [CrossRef] [PubMed]

256. Monaco, A.; Ferrandino, I.; Boscaino, F.; Cocca, E.; Cigliano, L.; Maurano, F.; Luongo, D.; Spagnuolo, M.S.; Rossi, M.; Bergamo, P. Conjugated linoleic acid prevents age-dependent neurodegeneration in a mouse model of neuropsychiatric lupus via the activation of an adaptive response. J. Lipid Res. 2018, 59, 48-57. [CrossRef] [PubMed]

257. Xu, L.; Zhang, C.; Jiang, N.; He, D.; Bai, Y.; Xin, Y. Rapamycin combined with MCC950 to treat multiple sclerosis in experimental autoimmune encephalomyelitis. J. Cell. Biochem. 2018. [CrossRef] [PubMed]

258. Chen, G.; Liu, S.; Pan, R.; Li, G.; Tang, H.; Jiang, M.; Xing, Y.; Jin, F.; Lin, L.; Dong, J. Curcumin Attenuates gp120-Induced Microglial Inflammation by Inhibiting Autophagy via the PI3K Pathway. Cell. Mol. Neurobiol. 2018, 38, 1465-1477. [CrossRef] [PubMed]

259. Li, B.; Wang, F.; Schall, N.; Muller, S. Rescue of autophagy and lysosome defects in salivary glands of MRL/lpr mice by a therapeutic phosphopeptide. J. Autoimmun. 2018, 90, 132-145. [CrossRef] [PubMed]

260. Wilhelm, M.; Wang, F.; Schall, N.; Kleinmann, J.-F.; Faludi, M.; Nashi, E.P.; Sibilia, J.; Martin, T.; Schaeffer, E.; Muller, S. Lupus regulator peptide P140 represses B-cell differentiation by reducing HLA class II molecule overexpression. Arthritis Rheumatol. 2018, 70, 1077-1088. [CrossRef] [PubMed]

261. Macri, C.; Wang, F.; Tasset, I.; Schall, N.; Page, N.; Briand, J.-P.; Cuervo, A.M.; Muller, S. Modulation of deregulated chaperone-mediated autophagy by a phosphopeptide. Autophagy 2015, 11, 472-486. [CrossRef] [PubMed]

262. Monneaux, F.; Lozano, J.M.; Patarroyo, M.E.; Briand, J.-P.; Muller, S. T cell recognition and therapeutic effect of a phosphorylated synthetic peptide of the 70K snRNP protein administered in MR/lpr mice. Eur. J. Immunol. 2003, 33, 287-296. [CrossRef] [PubMed]

263. Zimmer, R.; Scherbarth, H.R.; Rillo, O.L.; Gomez-Reino, J.J.; Muller, S. Lupuzor/P140 peptide in patients with systemic lupus erythematosus: A randomised, double-blind, placebo-controlled phase IIb clinical trial. Ann. Rheum. Dis. 2013, 72, 1830-1835. [CrossRef] [PubMed]

264. Deczkowska, A.; Schwartz, M. Targeting neuro-immune communication in neurodegeneration: Challenges and opportunities. J. Exp. Med. 2018, 215, 2702-2704. [CrossRef] [PubMed] 
265. Garbuzova-Davis, S.; Ehrhart, J.; Sanberg, P.R.; Borlongan, C.V. Potential role of humoral IL-6 cytokine in mediating pro-inflammatory endothelial cell response in amyotrophic lateral sclerosis. Int. J. Mol. Sci. 2018, 19, 423. [CrossRef] [PubMed]

266. Sankowski, R.; Mader, S.; Valdés-Ferrer, S.I. Systemic inflammation and the brain: Novel roles of genetic, molecular, and environmental cues as drivers of neurodegeneration. Front. Cell. Neurosci. 2015, 9, 28. [CrossRef] [PubMed]

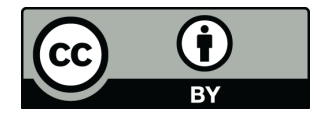

(C) 2018 by the authors. Licensee MDPI, Basel, Switzerland. This article is an open access article distributed under the terms and conditions of the Creative Commons Attribution (CC BY) license (http:/ / creativecommons.org/licenses/by/4.0/). 